\title{
How Do States' Safety Net Policies Affect Poverty?
}

Laura Wheaton, Linda Giannarelli, Michael Martinez-Schiferl, and Sheila Zedlewski

Working Families

Paper 19

September 2011

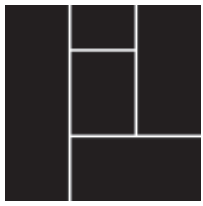

The Urban Institute 2100 M Street, NW Washington, DC 20037 
Copyright (C) September 2011. The Urban Institute. All rights reserved. Except for short quotes, no part of this paper may be reproduced in any form or used in any form by any means, electronic or mechanical, including photocopying, recording, or by information storage or retrieval system, without written permission from the Urban Institute.

This report is part of the Urban Institute's Low-Income Working Families project, a multiyear effort that focuses on the privateand public-sector contexts for families' success or failure. Both contexts offer opportunities for better helping families meet their needs. The Low-Income Working Families project is currently supported by The Annie E. Casey Foundation.

The authors would like to thank Erika Huber for her outstanding research assistance in helping to produce summary tables and graphics for the paper. Joyce Morton and Jessica Kelly provided excellent programming assistance, and Keith Watson and Kye Lippold played key roles on imputations and simulations. The authors also gratefully acknowledge Thesia Garner of BLS for providing the SPM thresholds used for this analysis, and Trudi Renwick and Kathleen Short of the Census Bureau, who provided guidance on SPM implementation. Finally, the authors recognize the key contribution of HHS/ASPE, the longtime primary funders of the CPS-based version of TRIM3.

The nonpartisan Urban Institute publishes studies, reports, and books on timely topics worthy of public consideration. The views expressed are those of the authors and should not be attributed to the Urban Institute, its trustees, or its funders. 


\section{CONTENTS}

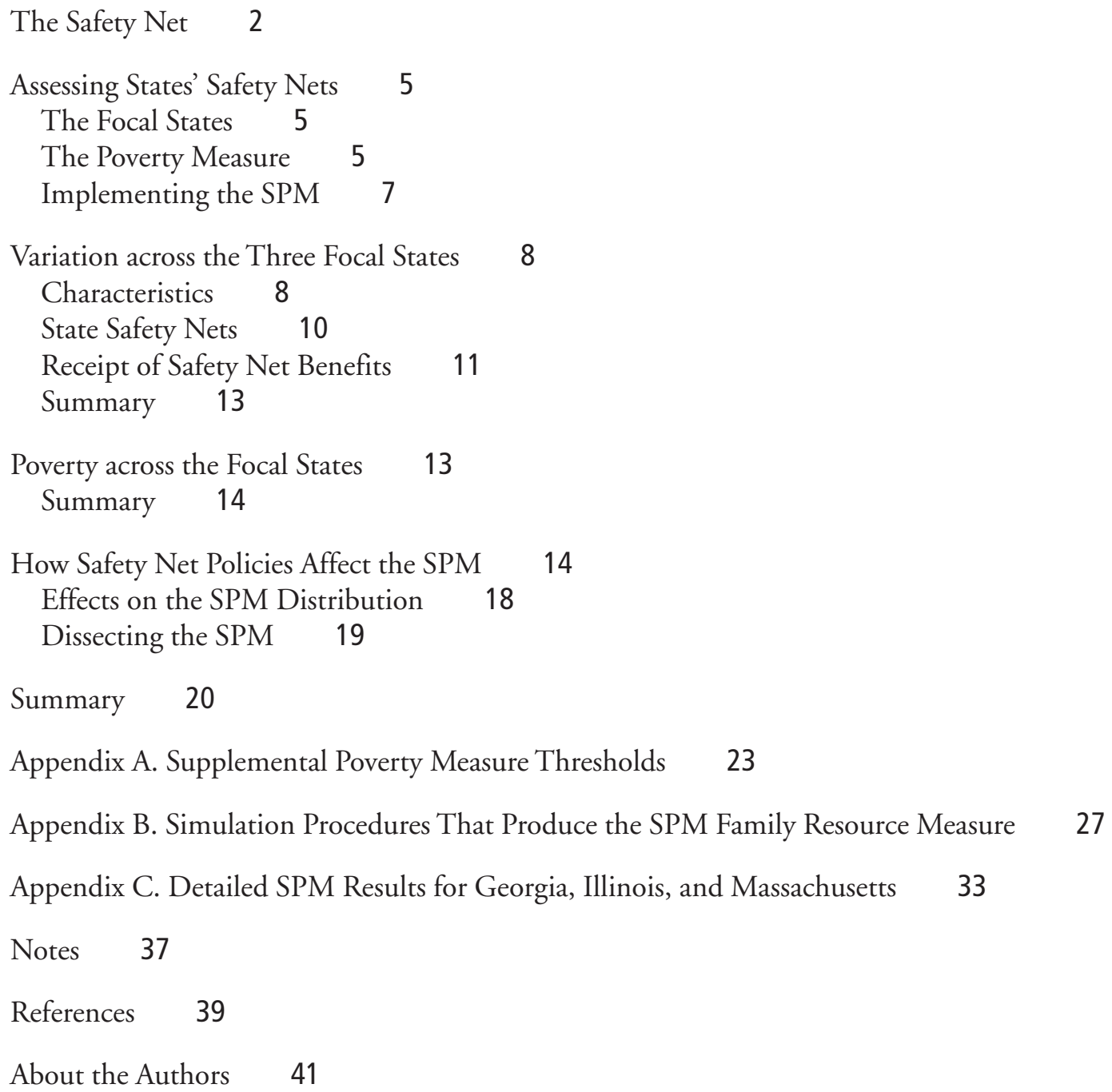





\section{HOW DO STATES' SAFETY NET POLICIES AFFECT POVERTY?}

The safety net is a broad array of federal and state programs that supports families through cash, food, housing assistance, and tax credits. Some are universal insurance programs that provide benefits regardless of other income and assets while others, often called means-tested programs, provide benefits to those with low incomes. Some federal programs operate the same across the country, and others allow for significant state administrative variation. The federal and state governments jointly fund other parts of the safety net, and eligibility and benefits vary across the states. States may also fund programs to fill in the gaps or augment federal programs. These variations mean that low-income families can face very different safety nets across the country.

This paper examines how safety net policy variation affects poverty among adults under age 65 and children. We measure the effects using a Supplemental Poverty Measure (SPM) that captures the effects of cash, noncash, and tax elements of the safety net and show the net effects on adult and child poverty. In 2009, the Office of Management and Budget formed an Interagency Technical Working Group (ITWG) on developing the SPM to provide an "improved understanding of the economic well-being

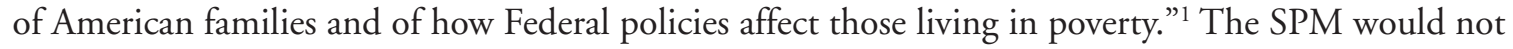
replace the official poverty measure, which is based only on cash income, but would supplement it. The SPM provides a useful benchmark for assessing the effectiveness of safety net policies.

We highlight the safety nets in three focal states: Georgia, Illinois, and Massachusetts. These states were chosen to illustrate the effects of narrow, medium, and broad safety nets. The results show how universal and means-tested programs affect poverty and how federal and state program rules have very different effects across states with different populations and economies. 
The paper begins with a summary of the safety net programs included in the assessment. The next section summarizes methods, including the data, the choice of focal states, the SPM metric, and the methods used to implement the SPM in the focal states. Then we describe the variation in demographic and economic characteristics and safety net policies across these states. The results show how the safety net policies affect both the official and SPM measures of poverty in the three states. Results also highlight how individual elements of the safety net affect poverty and net incomes throughout the income distribution.

Federal and state safety net programs substantially reduce poverty, especially among children. The focal states' safety net policies have substantially different effects on poverty, but federal policies tend to smooth out differences across the three focal states.

\section{The Safety Net}

There is no single definition of the safety net. We focus our analysis on the largest programs that provide cash or near-cash support to nonelderly families that experience unemployment, disability, death, or low income (table 1). ${ }^{2}$ Programs are categorized as universal cash, means-tested cash, and means-tested noncash programs.

Universal cash benefit programs include Social Security and unemployment insurance (UI). Both pay benefits to insured workers and sometimes their dependents in the event of a loss of earnings. They are universal because individuals can receive benefits regardless of their other income or resources. Both programs rely on payroll taxes for financing. Social Security benefits do not vary across the country, but states set UI eligibility and benefit rules.

Social Security benefits for nonelderly families are contingent on a loss of earnings due to severe disability or death. For young workers, eligibility generally requires earnings in covered employment in 5 of the last 10 years. Benefits are defined by a progressive formula that replaces a larger share of earnings for lower-earning than higher-earning workers. The dependents of insured workers (spouse and children under age 18) qualify for benefits set at approximately half the worker's benefit. While most think of Social Security as a retirement program, disability, survivor, and dependent benefits substantially reduce poverty among children (Gabe 2008).

Insured workers who lose a job involuntarily may qualify for unemployment insurance. State programs vary in whether they cover unemployment among part-time covered workers, how they define the base period for wage determination, and whether they allow for benefits for workers that quit for good reason. The regular UI program usually provides benefits for 26 weeks. Two additional tiers of benefits can extend coverage. The federal-state extended benefits program (EB) can pay an additional 13 to 20 weeks of regular UI, and the federal temporary extended unemployment compensation (EUC) program enacted in June 2008 can provide as many as 53 additional weeks of benefits. ${ }^{3}$ Benefit levels generally depend on past wages up to a maximum; 13 states provided some benefits for dependents in $2008 .{ }^{4}$ As a result of the strict eligibility rules, many unemployed workers do not qualify for benefits. For example, from 1998 to 2007, the share of unemployed workers that qualified for benefits ranged from less than 20 percent in five states (Colorado, Florida, South Dakota, Texas, and Virginia) to above 45 percent in others (Alaska, Connecticut, Massachusetts, New Jersey, and Rhode Island; see Vroman 2009).

Means-tested cash benefit programs include Temporary Assistance for Needy Families (TANF), General Assistance (GA), and Supplemental Security Income (SSI). TANF provides cash benefits to low-income, 
TABLE 1. Key Safety Net Programs in 2008

\begin{tabular}{|c|c|c|c|}
\hline Program & Characteristics & $\begin{array}{l}\text { Administrative \& funding } \\
\text { responsibility }\end{array}$ & Key state variation \\
\hline \multicolumn{4}{|l|}{ Universal cash } \\
\hline Social Security & $\begin{array}{l}\text { Cash benefit due insured } \\
\text { individual \& dependents for } \\
\text { retirement, death, disability. }\end{array}$ & $\begin{array}{l}\text { All federal; wage tax covers } \\
\text { cost. }\end{array}$ & None. \\
\hline $\begin{array}{l}\text { Unemployment } \\
\text { insurance } \\
\text { (regular) }\end{array}$ & $\begin{array}{l}\text { Cash benefit due individual if } \\
\text { involuntarily unemployed \& } \\
\text { insured. }\end{array}$ & $\begin{array}{l}\text { States set rules; wage tax } \\
\text { covers regular benefits; } \\
\text { federal revenues if high } \\
\text { unemployment. }\end{array}$ & $\begin{array}{l}\text { Minimum and maximum benefit } \\
\text { levels; base period definition for } \\
\text { eligibility and benefit; part-time } \\
\text { eligibility; dependent coverage. }\end{array}$ \\
\hline \multicolumn{4}{|c|}{ Means-tested cash } \\
\hline TANF & $\begin{array}{l}\text { Cash benefits to families with } \\
\text { children, very low income } \\
\text { and assets. Limited. }\end{array}$ & $\begin{array}{l}\text { State sets rules within } \\
\text { federal constraints. }\end{array}$ & $\begin{array}{l}\text { Benefit levels; time limits; } \\
\text { diversion strategies. }\end{array}$ \\
\hline $\begin{array}{l}\text { General } \\
\text { Assistance }\end{array}$ & $\begin{array}{l}\text { Cash or voucher to very poor } \\
\text { not eligible for other } \\
\text { programs; often for } \\
\text { unemployable. Limited. }\end{array}$ & $\begin{array}{c}\text { All states, } 33 \text { statewide } \\
\text { programs in } 2006 .\end{array}$ & $\begin{array}{l}\text { Benefit levels; whether cash or } \\
\text { voucher; eligibility groups. }\end{array}$ \\
\hline SSI & $\begin{array}{l}\text { Cash to low-income elderly } \\
\text { and seriously disabled } \\
\text { children and adults. } \\
\text { Entitlement. }\end{array}$ & $\begin{array}{l}\text { Federal benefit and asset } \\
\text { limits; state administered. }\end{array}$ & Benefit supplements. \\
\hline \multicolumn{4}{|c|}{ Means-tested noncash } \\
\hline $\begin{array}{l}\text { Supplemental } \\
\text { Nutrition } \\
\text { Assistance } \\
\text { (SNAP) }\end{array}$ & $\begin{array}{l}\text { EBT card to pay for food for } \\
\text { households with income } \\
<130 \% \text { FPL. Entitlement. }\end{array}$ & $\begin{array}{l}\text { Federal benefit and } \\
\text { eligibility requirements; } \\
\text { states administer; state } \\
\text { options. }\end{array}$ & $\begin{array}{l}\text { Certification period; asset limits; } \\
\text { access variability; countable } \\
\text { income and deductions. }\end{array}$ \\
\hline $\begin{array}{l}\text { Housing } \\
\text { Assistance }\end{array}$ & $\begin{array}{l}\text { Rent vouchers or public } \\
\text { housing unit for low-income } \\
\text { households; limits rent to } \\
30 \% \text { of income. Limited. }\end{array}$ & $\begin{array}{l}\text { Federal, administered by } \\
\text { state housing authorities. }\end{array}$ & $\begin{array}{l}\text { Vouchers and public housing units } \\
\text { allocated across states using a } \\
\text { complex formula with } \\
\text { numerous historic components. }\end{array}$ \\
\hline Child care & $\begin{array}{l}\text { Reduces cost of child care for } \\
\text { low-income families. }\end{array}$ & $\begin{array}{l}\text { State rules with federal and } \\
\text { state funding. }\end{array}$ & $\begin{array}{l}\text { Eligibility for subsidy, copays, } \\
\text { maximums. }\end{array}$ \\
\hline \multicolumn{4}{|c|}{ Refundable tax credits } \\
\hline $\begin{array}{l}\text { Federal tax } \\
\text { credits }\end{array}$ & $\begin{array}{l}\text { EITC for low earners, child tax } \\
\text { credit phases out at } \\
\$ 110,000 \mathrm{AGI} \text { for a joint } \\
\text { return and } \$ 75,000 \text { for } \\
\text { single filers. Entitlement. }\end{array}$ & Federal. & None. \\
\hline State tax credits & $\begin{array}{l}\text { EITC \& low-income credits. } \\
\text { Entitlement. }\end{array}$ & States. & $\begin{array}{l}\text { EITC often piggybacks on federal } \\
\text { EITC; other low-income credits. }\end{array}$ \\
\hline
\end{tabular}

Source: Compiled from various state plans.

Entitlement $=$ benefits available to all eligible; limited $=$ benefits available until money runs out; FPL $=$ federal poverty level 
low-asset families with children under age 18 , and parents generally are subject to work requirements. The federal government funds about 60 percent of the cost of this program through a fixed block grant set in 1996, and states fund the remainder through maintenance of effort requirements. While the federal government gives states broad leeway to define their programs, it requires state programs to meet minimum work participation requirements and prohibits use of federal dollars for payments beyond five years. State benefit levels, time limits, and strategies that divert families from enrolling in the program vary tremendously.

Statewide GA programs operate in about 33 states and generally provide either cash benefits or vouchers for unemployable adults and sometimes families with children that do not qualify for TANF. States are fully responsible for GA program funds and benefit rules.

SSI, in contrast, operates across all states with federal eligibility and benefit rules. SSI provides benefits to severely disabled adults and children and requires strict income and asset limits for eligibility. States may supplement the federal benefit.

Means-tested noncash benefit programs include Supplemental Nutrition Assistance (SNAP), housing assistance, and child care subsidies. SNAP is a federal program providing an electronic benefits transfer (EBT) card to low-income households to purchase food. While benefit levels are the same across the country and vary primarily by household size and income level, states can adopt many options that affect eligibility, deductions from income, access, and allowable asset levels. In 2008, estimated participation rates (the share of eligible households that enrolled) ranged from about 50 percent (in California, Colorado, Idaho, Nevada, and Wyoming) to 80 percent or more (in D.C., Illinois, Kentucky, Maine, Michigan, Missouri, Tennessee, Washington, and West Virginia; see Cunnyngham and Castner 2010).

The federal government subsidizes renters through Section 8 Housing Choice Vouchers and public housing. These programs generally limit the rent of low-income families (most have incomes at or below 30 percent of area median income) to a maximum of 30 percent of their income (adjusted for necessary expenses). These are not entitlement programs. Families that apply for assistance typically wait several months to many years for assistance. ${ }^{5}$ The distribution of vouchers and public housing across states and local areas results from various allocation methods used over the years, and Congress has often modified the exact distribution formula in the appropriations process (U.S. Ways and Means Committee 2009).

Child care subsidies complete this set of noncash benefits. Low-income working families may receive a voucher to pay for child care (or the provider is paid directly). States operate the largest program, the Child Care and Development Fund (CCDF), which receives a large part of its funding directly through the federal government, plus a share of the TANF block grant and state contributions. Eligibility and subsidy levels are defined by the states, and most cannot provide subsidies for all families that qualify.

Another important element of the safety net is refundable tax credits. The federal earned income tax credit (EITC) provides a substantial refundable credit for earners with children (up to $\$ 4,824$ for earners with two or more children in 2008) and a much smaller benefit for earners without children (a maximum of $\$ 438$ in 2008). In 2008, 24 states (including the District of Columbia) augmented this credit by adding a state EITC, usually a percentage of the federal credit; the credits are also refundable in 21 states (Levitis and Koulish 2008). States may also provide other types of low-income tax credits. The federal child tax credit enables lower- and middle-income families to subtract $\$ 1,000$ from their taxes for each qualifying child under the age of 17 . If the amount of the child tax credit exceeds what the fam- 
ily owes in taxes, then the family may be eligible to receive some or all of the excess amount through the refundable portion of the child tax credit (also known as the additional child tax credit). ${ }^{6}$

The safety net provides critical help to many low-income families. Differences by state vary considerably across safety net programs. Social Security and federal tax credits provide an entitlement to benefits with no variation across the country. SSI is also a federal entitlement with standard benefits paid across the country, but some states supplement this benefit. The states play the major role in defining who gets UI, TANF, GA, state tax credits, and child care subsidies and how much they get. Housing assistance is a unique federal program with benefits that vary with rental costs across the country, and the number of assisted units available depends on numerous factors, including historic trends.

\section{Assessing States' Safety Nets}

An assessment of how these various safety net programs augment the net incomes of low-income families requires examining the rules by state and assessing the variation in family needs across states. All else equal, states with more generous safety net policies provide more assistance per low-income family.

\section{The Focal States}

Given wide variety in policies and family needs across all 50 states, we focus on three states to illustrate different safety net policies. We purposefully chose states representing relatively low, moderate, and generous safety net policies. We reviewed states' maximum benefits for TANF, UI, and refundable tax credits to assess generosity. We limited the choice to states of fair size and those that did not vary their safety net policies substantially across the state. We also tried to limit the variation in pre-safety net income across the focal states by choosing states with similar unemployment rates in 2008 and similar child poverty rates once safety net benefits were removed and incomes adjusted for variation in cost of living. These factors led us to choose Georgia to illustrate a state with a relatively limited safety net policy, Illinois with a moderate policy, and Massachusetts with a generous policy.

\section{The Poverty Measure}

This assessment requires a metric that incorporates all the key safety net programs described above. The official poverty rate is based only on cash income and only includes variation in Social Security, UI, TANF, GA, and SSI. In contrast, the SPM includes cash and noncash benefits, and the effect of taxes and other necessary expenses on poverty (table 2). The SPM includes the effects of SNAP, housing subsidies, federal and state income taxes, and necessary work expenses (child care, transportation, and other workrelated expenses). ${ }^{7}$ As noted above, federal agencies are still working out specific details of the SPM. We implement the 2010 research version of the SPM as closely as possible for this analysis (see Short 2011).

The thresholds defining poverty also vary between the two poverty definitions. The official poverty threshold is constant across the country, varies by family size and number of children, and assumes that the elderly require less income than the nonelderly. The SPM also varies by family size and number of children, but it does not assume lower thresholds for the elderly and includes adjustments for whether a family rents or owns a home with or without a mortgage and for geographic differences in housing costs. The official poverty thresholds, first set in 1963, were originally based on the cost of the USDA's "Economy Food Plan" developed from a 1955 household expenditure survey and multiplied by three, the estimated share of income spent on food. The official poverty thresholds are adjusted annually for price changes using the consumer 
TABLE 2. Resource Definitions for Official and Supplemental Poverty Measures

\begin{tabular}{|c|c|c|}
\hline Concepts & Census official & Supplemental (SPM) \\
\hline Resources & $\begin{array}{l}\text { Cash Income: } \\
\text { Wages, salaries, self-employment } \\
\text { Interest, dividends, rent, trusts } \\
\text { Social Security \& Railroad Retire. } \\
\text { Pensions } \\
\text { Disability benefits } \\
\text { Unemployment compensation } \\
\text { Child support } \\
\text { Veterans benefits } \\
\text { Educational assistance } \\
\text { Supplemental Security Income } \\
\text { TANF } \\
\text { Other cash public assistance }\end{array}$ & $\begin{array}{l}\text { Cash Income: } \\
\text { Same as components shown for "official" measure. } \\
\text { + Food Stamps/SNAP } \\
\text { + housing subsidies } \\
\text { + LIHEAP (omitted)a } \\
\text { + WIC (omitted) } \\
\text { + school lunch (omitted) } \\
\text { - federal income tax } \\
\text { - payroll taxes } \\
\text { - state income taxes } \\
\text { + federal EITC } \\
\text { + state EITC } \\
\text { - child support payments (omitted) } \\
\text { - child care expenses } \\
\text { - other work expenses }\end{array}$ \\
\hline Thresholds & $\begin{array}{l}\text { National thresholds vary by age (less than } 65 \\
\text { and 65+) and number of children and } \\
\text { adults. The original thresholds were based } \\
\text { on the share of income spent on food under } \\
\text { an "Economy Food Plan" developed from a } \\
1955 \text { expenditure survey. The thresholds are } \\
\text { adjusted annually for price changes using } \\
\text { the CPI. }\end{array}$ & $\begin{array}{l}\text { Thresholds vary by number of children and adults and } \\
\text { housing status (owns with mortgage, owns without } \\
\text { mortgage, or rents) and reflect the 33rd percentile of } \\
\text { expenditures by families with two children on a } \\
\text { basic set of goods (food, housing, utilities, clothing, } \\
\text { out-of-pocket medical costs) plus a little more based } \\
\text { on five years of Consumer Expenditures Survey } \\
\text { data. }{ }^{b} \text { Geographic adjustments are applied to the } \\
\text { housing portion of the threshold, and the medical } \\
\text { portion is adjusted by insurance, health, and } \\
\text { elderly/nonelderly status. }\end{array}$ \\
\hline
\end{tabular}

a. LIHEAP, WIC, School Lunch, and child support payments are excluded because they are not reported on the survey nor simulated.

b. See Garner (2010, 2011a) and Short (2011) for a description of the SPM thresholds. The standard SPM deducts medical out-of-pocket (MOOP) costs from income as a necessary expense. Lacking an estimate of this expense, we use alternative BLS thresholds that include these costs (Garner $2011 \mathrm{~b})$.

price index but have otherwise changed little since their original adoption more than 40 years ago. The SPM threshold is based on out-of-pocket spending for food, clothing, shelter, and utilities, with a multiplier of 1.2 to provide for additional basic needs. The threshold is calculated using five years of recent Consumer Expenditure Survey data and reflects spending at the 33rd percentile for families with two children. The version of the SPM thresholds used for this analysis also includes out-of-pocket health care spending, adjusted by family health insurance, health, and elderly/nonelderly status. In addition, we adjust the housing portion of the SPM threshold for geographic variation in housing costs by Super-PUMA (Census Bureau-defined state subsections comprising populations of 400,000 or more).

The differences in the resources underlying the measures and the threshold calculations produce substantially different thresholds across the states (table 3). (Appendix A provides more detail on the thresholds used in the three states.) In 2008, the official poverty threshold was $\$ 21,834$ for a two-adult, two-child family. The SPM threshold before adjusting for differences in renter/owner status, medical out-of-pocket expenses, and geographic variation in housing costs was $\$ 25,997 .{ }^{8}$ After applying these adjustments to each family's threshold, the resulting average threshold for a two-adult, two-child fam- 
TABLE 3. Poverty Thresholds for Two Adults, Two Children: Variation across States, 2008

\begin{tabular}{|c|c|c|c|c|}
\hline & \multirow[b]{2}{*}{ Overall } & \multicolumn{3}{|c|}{ Housing Status } \\
\hline & & Rent & $\begin{array}{l}\text { Own with } \\
\text { mortgage }\end{array}$ & $\begin{array}{l}\text { Own without } \\
\text { mortgage }\end{array}$ \\
\hline Official threshold & $\$ 21,834$ & - & - & - \\
\hline SPM threshold & $\$ 25,997$ & $\$ 26,252$ & $\$ 26,660$ & $\$ 21,860$ \\
\hline \multicolumn{5}{|c|}{$\begin{array}{l}\text { SPM thresholds averaged over state population, } \\
\text { with geographic, medical risk, and housing } \\
\text { status adjustments }\end{array}$} \\
\hline Georgia & $\$ 24,778$ & $\$ 24,313$ & $\$ 25,402$ & $\$ 20,276$ \\
\hline Illinois & $\$ 25,959$ & $\$ 25,270$ & $\$ 26,512$ & $\$ 21,194$ \\
\hline Massachusetts & $\$ 29,694$ & $\$ 29,111$ & $\$ 30,189$ & $\$ 24,019$ \\
\hline
\end{tabular}

Notes: SPM thresholds are obtained from Garner (2011b). See appendix A for discussion of adjustments by family size, health status, and housing cost variation across state metropolitan and nonmetropolitan areas.

ily in Georgia was $\$ 24,778$. The average threshold in Illinois was $\$ 25,959$ (about 5 percent higher than Georgia), and the threshold in Massachusetts was \$29,694 (about 20 percent higher than Georgia). As shown, the thresholds for homeowners with no mortgage are significantly lower than average, and the thresholds for those who own with a mortgage are higher.

\section{Implementing the SPM}

The analysis requires a representative survey with sufficient sample for individual state analysis. We use the 2008 American Community Survey (ACS) representative of 2008 income for this analysis. The survey provides large samples for each state: approximately 92,000 total persons in Georgia, 123,000 in Illinois, and 62,000 in Massachusetts. Since we focus on safety net policies serving families under age 65 and children, we tabulate results only for these populations. In families where children live with elderly heads, however, we include those adults so the population covers all families with children in the three focal states. ${ }^{9}$

While the ACS includes key demographic information and asks households about their employment and income during the year, it lacks many elements required for the SPM. Some of the missing elements are SNAP benefit amounts, receipt and amounts of housing assistance, taxes (federal and state), and work expenses. Some available ACS data elements are not sufficiently accurate for detailed state-level analysis. For example, some income sources are combined into one variable (UI, veterans benefits, child support) and others fall considerably short of administrative program totals (SNAP receipt, SSI, welfare). Therefore, the analysis requires a considerable number of data imputations and corrections. Generally, we use simulation procedures implemented through the TRIM3 model to implement each element of income, taxes, and expenses at the household level. The simulation processes mimic the individual program rules in each focal state during 2008. The results of each imputation are compared with administrative data to assess their accuracy, and repeated simulations align the totals to administrative data. (See appendix B for details.)

The result of the simulation process is a set of augmented ACS data representative of families living in the three focal states. Results are tabulated using both the official and the SPM poverty measures. We frequently 
show family "pre-safety net" (or "private") income that excludes all government safety net benefits to show the effects of safety net programs and how families that are poor based on their pre-safety net income move across the poverty income distribution once all government assistance and elements of the SPM are calculated.

\section{Variation across the Three Focal States}

Differences in family characteristics and safety net policies across the three states provide the context for understanding differences in poverty. For example, safety net policies that target children will have a larger effect overall if the state's low-income population tends to consist primarily of families with children. Policies focused on low-income workers will have a larger effect if a state has relatively more working poor families. Differences across the state populations also intersect with the SPM poverty thresholds. For example, relatively higher homeownership rates mean that, on average, families will need more resources to move above the poverty threshold.

\section{Characteristics}

The nonelderly populations vary in some important ways across the three focal states (table 4). Massachusetts has the smallest population (2.17 million nonelderly families) of the three; Georgia is in the middle (3.18 million) and Illinois has the largest (4.09 million). The pre-safety net poor population, the primary group targeted by the safety net, makes up about 19 percent of the nonelderly population in Georgia and 17 percent in Illinois and Massachusetts. Family structure among all nonelderly families varies somewhat; Massachusetts has relatively more families without children than the other two states (64 percent compared with about 60 percent). This difference carries over to the pre-safety net poor population. Average family size is smaller in Massachusetts, especially among the lower-income group. The age distributions across the states are quite similar for all families and lower-income families. Younger family heads (under age 34) make up much larger shares of the pre-safety net poor populations in all three states than in the general population.

The race/ethnicity distributions vary across the three states. Overall, Massachusetts has the highest percentage of white families (79 percent), Georgia has the highest percentage of black families (30 percent), and Illinois has the highest percentage of Hispanic families (13 percent). Blacks and Hispanics make up greater shares of the pre-safety net poor population than of the general population in all three states, although whites continue to make up most of the lower-income group in Massachusetts.

Housing tenure varies relatively little across the three states, although Massachusetts families are more likely to rent and less likely to own a home without a mortgage than families in Georgia or Illinois. In all three states, the lower-income families are predominantly renters. Within-state geographic distributions also vary; Georgia has a more rural population and Massachusetts a more urban one. Similar to all families, pre-safety net poor families in Massachusetts are much more likely to live in urban areas (94 percent compared with 65 percent in Georgia and 82 percent in Illinois), and pre-safety net poor families in Georgia are more likely to live in rural areas (28 percent compared with 14 percent in Illinois and 1 percent in Massachusetts).

While work status is similar across the three states for the general nonelderly population, some differences exist for pre-safety net poor families. For example, pre-safety net poor families in Massachusetts are less likely to include at least one full-time worker (14 percent compared with 21 percent in Georgia and Illinois). 
TABLE 4. Family Characteristics by State, 2008 (SPM Units Containing Children or Nonelderly Heads)

\begin{tabular}{|c|c|c|c|c|c|c|}
\hline & \multicolumn{3}{|c|}{ All } & \multicolumn{3}{|c|}{ Pre-Safety Net Poor ${ }^{a}$} \\
\hline & GA & IL & MA & GA & IL & MA \\
\hline Number of Families (thousands) & 3,180 & 4,089 & 2,170 & 603 & 689 & 370 \\
\hline Average Unit Size & 2.5 & 2.6 & 2.4 & 2.3 & 2.4 & 2.0 \\
\hline Average Pre-Safety Net Income ${ }^{b}$ & 65,883 & 75,089 & 85,330 & 7,548 & 7,979 & 7,666 \\
\hline \multicolumn{7}{|l|}{ Family structure } \\
\hline $\begin{array}{l}\text { Two parents with children (includes } \\
\text { cohabitors) }{ }^{c}\end{array}$ & 25.8 & 28.0 & 25.8 & 12.6 & 14.6 & 10.6 \\
\hline One parent with children & 10.5 & 9.0 & 8.3 & 21.9 & 20.9 & 20.6 \\
\hline Other families with children & 4.2 & 3.1 & 2.3 & 6.6 & 5.1 & 2.8 \\
\hline Other & 59.5 & 59.9 & 63.5 & 59.0 & 59.4 & 66.0 \\
\hline \multicolumn{7}{|l|}{ Age of Family Head } \\
\hline$<34$ & 29.6 & 29.1 & 27.5 & 41.9 & 43.2 & 40.7 \\
\hline 34-49 & 41.8 & 40.5 & 41.0 & 31.0 & 29.2 & 30.8 \\
\hline $50+$ & 28.6 & 30.5 & 31.5 & 27.1 & 27.7 & 28.6 \\
\hline \multicolumn{7}{|l|}{ Race } \\
\hline White, non-Hispanic & 58.6 & 67.2 & 79.4 & 42.2 & 48.4 & 62.2 \\
\hline Black, non-Hispanic & 29.8 & 14.1 & 5.5 & 40.6 & 27.0 & 9.5 \\
\hline Hispanic & 7.5 & 12.9 & 8.4 & 12.6 & 18.1 & 19.1 \\
\hline Other & 4.1 & 5.8 & 6.7 & 4.5 & 6.4 & 9.2 \\
\hline \multicolumn{7}{|l|}{ Housing Tenure } \\
\hline Rent & 38.1 & 35.3 & 40.4 & 68.6 & 69.1 & 77.1 \\
\hline Own without mortgage & 11.0 & 11.4 & 8.9 & 10.3 & 8.7 & 5.7 \\
\hline Own with mortgage & 50.9 & 53.3 & 50.6 & 21.2 & 22.2 & 17.2 \\
\hline \multicolumn{7}{|l|}{ Geography } \\
\hline Urban & 70.4 & 83.4 & 91.3 & 65.3 & 82.4 & 93.7 \\
\hline Rural & 23.2 & 12.1 & 1.9 & 28.3 & 13.6 & 1.4 \\
\hline Not identified & 6.3 & 4.5 & 6.8 & 6.3 & 4.0 & 4.9 \\
\hline \multicolumn{7}{|l|}{ Work Status } \\
\hline At least one adult full time ${ }^{d}$ & 74.0 & 74.3 & 72.0 & 21.3 & 20.6 & 13.6 \\
\hline Some work (among adults) & 17.2 & 17.7 & 19.6 & 41.0 & 43.0 & 45.8 \\
\hline No work (among adults) & 8.8 & 8.0 & 8.5 & 37.7 & 36.5 & 40.6 \\
\hline
\end{tabular}

Source: TRIM3 using 2008 American Community Survey.

a. Units with pre-safety net income lower than the SPM poverty threshold.

b. Pre-safety net income includes cash income before cash and noncash government benefits, and tax credits. Workers compensation and veterans benefits are included in pre-safety net income because these benefits are reported as other income on the ACS.

c. The cohabiting partner is not necessarily the biological or adoptive parent of any children in the unit.

$\mathrm{d}$. At least one person in the unit is age 18 or older, works 50 or more weeks in the year, and usually works 35 hours or more a week. 


\section{State Safety Nets}

We chose three focal states that illustrate narrow, moderate, and broad safety net policies (table 5). UI and TANF benefits are highest in Massachusetts and lowest in Georgia. Georgia does not have a statewide GA program, but Illinois and Massachusetts have programs for both unemployable adults and families with children that do not qualify for TANF. Illinois and Massachusetts pay supplements to federal SSI benefits, but the amounts are higher in Massachusetts than in Illinois.

Means-tested noncash benefits also differ. SNAP rules vary relatively little across these three states, although certification periods (how long a family can keep benefits before reapplying) are longer in Illinois than in the other states (12 months rather than 6 months), and Georgia and Massachusetts offer

TABLE 5. Safety Net Policy Variation across Focal States, 2008

\begin{tabular}{|c|c|c|c|c|}
\hline Program & Program element & Georgia & Illinois & Massachusetts \\
\hline \multicolumn{5}{|l|}{ Universal Cash } \\
\hline Social Security & No variation. & & & \\
\hline $\begin{array}{l}\text { Unemployment } \\
\text { insurance (regular } \\
\text { program) }\end{array}$ & $\begin{array}{l}\text { Max benefit/week; } \\
\text { max weeks. }\end{array}$ & $\$ 320 ; 26$ weeks. & $\begin{array}{l}\text { \$385-634; } \\
26 \text { weeks. }\end{array}$ & $\begin{array}{r}\$ 628-\$ 942 ; \\
30 \text { weeks. }\end{array}$ \\
\hline \multicolumn{5}{|l|}{ Means-Tested Cash } \\
\hline TANF & $\begin{array}{l}\text { Max benefit if } \\
0 \text { income; } \\
\text { time limit. }\end{array}$ & $\$ 280 ; 48$ mos. & $\$ 432 ; 60$ mos. & $\$ 633 ;$ no limit. \\
\hline General Assistance & $\begin{array}{l}\text { Monthly benefit; } \\
\text { eligibility. }\end{array}$ & No program. & $\begin{array}{l}\text { \$154-65 (single } \\
\text { unemployable } \\
\text { adults); } \\
\text { \$389-414 } \\
\text { (4-person } \\
\text { families). }\end{array}$ & $\begin{array}{l}\text { \$304 (1-person } \\
\text { family) +\$93 a } \\
\text { mo. per person. } \\
\text { Unemployable } \\
\text { adults + families } \\
\text { not eligible for } \\
\text { TANF. }\end{array}$ \\
\hline SSI & Monthly supplement. & None. & $\begin{array}{l}\text { Average } \$ 79 / \\
\text { person (varies). }\end{array}$ & $\begin{array}{l}\$ 120 \text { (person); } \\
\quad \$ 195 \text { (couple). }\end{array}$ \\
\hline \multicolumn{5}{|c|}{ Means-Tested Noncash } \\
\hline $\begin{array}{l}\text { Supplemental Nutrition } \\
\text { Assistance (SNAP) }\end{array}$ & Asset limits. & $\begin{array}{l}\text { Certify for } 6 \text { mos.; } \\
\text { expanded } \\
\text { categorical } \\
\text { eligibility. }\end{array}$ & Certify for 12 mos. & $\begin{array}{l}\text { Certify for } 6 \text { mos.; } \\
\text { expanded } \\
\text { categorical } \\
\text { eligibility. }\end{array}$ \\
\hline Housing Assistance & $\begin{array}{l}\text { Number; fair-market } \\
\text { rent (FMR), 2-bed } \\
\text { urban. }\end{array}$ & $\begin{array}{l}.014 \text { vouchers/ } \\
\text { capita; \$764 FMR. }\end{array}$ & $\begin{array}{l}.017 \text { vouchers/ } \\
\text { capita; } \$ 876 \\
\text { FMR. }\end{array}$ & $\begin{array}{l}.029 \text { vouchers/ } \\
\text { capita; } \\
\text { \$1,181 FMR. }\end{array}$ \\
\hline $\begin{array}{l}\text { Child care subsidies } \\
\text { (CCDF) }\end{array}$ & $\begin{array}{l}\text { Reduces cost of child } \\
\text { care for low-income } \\
\text { families. }\end{array}$ & $\begin{array}{l}\text { Eligibility limit for } \\
\text { family of } 3 \text { : } \\
\$ 2,213 \text {. }\end{array}$ & $\begin{array}{l}\text { Eligibility limit } \\
\text { for family of } 3 \text { : } \\
\$ 2,647 \text {. }\end{array}$ & $\begin{array}{l}\text { Eligibility limit for } \\
\text { family of } 3 \text { : } \\
\$ 2,990 \text {. }\end{array}$ \\
\hline Federal tax credits & None. & - & - & - \\
\hline State tax credits & $\begin{array}{l}\text { EITC \& low-income } \\
\text { credits. Entitlement. }\end{array}$ & $\begin{array}{c}\$ 26 / \text { dependent if } \\
\text { AGI }<\$ 20,000 \\
\text { and no SNAP. }\end{array}$ & $\begin{array}{l}5 \% \text { of federal } \\
\text { EITC. }\end{array}$ & $15 \%$ of federal EITC. \\
\hline
\end{tabular}

Source: Compiled from various state plans. 
expanded categorical eligibility. Fewer housing assistance vouchers are available per capita in Georgia $(0.014)$ than in Illinois $(0.017)$ or Massachusetts $(0.029)$. The monthly average fair-market rent values for two-bedroom urban units vary from $\$ 764$ in Georgia to $\$ 876$ in Illinois and \$1,181 in Massachusetts, so voucher values also vary across these states.

The federal EITC and refundable child tax credits are the same across the country. However, the maximum amount of these credits represents a higher share of the poverty threshold in lower-threshold states such as Georgia, increasing their antipoverty potential. In addition, poor families in higher poverty threshold states such as Massachusetts have incomes further into the phase out range of the federal EITC, where benefit amounts are lower, thereby reducing the potential antipoverty effect. The state tax credits offset this effect somewhat. Illinois provides an EITC of 5 percent on top of the federal credit, and Massachusetts provides a 15 percent credit. Of course, only families with earnings qualify for these refundable state credits. Georgia in contrast, provides a small tax credit (\$26 per dependent) to all low-income families.

Child care subsidies are also important because they can substantially reduce these necessary expenses among working families. Massachusetts has the highest monthly income thresholds for eligibility for CCDF-funded child care subsidies ( $\$ 2,990$ for a three-person family, compared with $\$ 2,647$ in Illinois and \$2,213 in Georgia).

\section{Receipt of Safety Net Benefits}

The receipt of benefits for all families and for pre-safety net poor families varies across the states (table 6). Considering cash assistance, the relatively high receipt of welfare (TANF and other) in Massachusetts stands out. Among all families, 4.2 percent receive welfare in Massachusetts compared with 1.4 and 1.8 percent, respectively, in Georgia and Illinois, and 18.1 percent of the pre-safety net poor group receives welfare in Massachusetts compared with 5.0 and 6.6 percent, respectively, in Georgia and Illinois. As shown earlier, Massachusetts provides the highest TANF benefit with no time limit, and its General Assistance benefit is higher than in Illinois (Georgia does not have a GA benefit). Receipt of SSI is also higher in Massachusetts than in Georgia and Illinois among the lower-income group (19.9 percent compared with 15.0 percent in Georgia and 13.8 percent in Illinois). Massachusetts offers the highest supplement to the federal benefit.

The receipt of noncash assistance also varies across the states. SNAP receipt is more common in Georgia and Illinois than in Massachusetts. As noted earlier, Illinois has a higher SNAP participation rate than most other states. In 2008, for example, 66 percent of eligible working families participated in SNAP in Illinois, compared with 53 percent in Georgia and 46 percent in Massachusetts (Cunnyngham and Castner 2010). The TRIM3 simulation results used for this analysis mimic these participation patterns since participants are selected to match program totals.

Receipt of public and subsidized housing reflects the greater availability of this benefit in Massachusetts relative to the other states. Among pre-safety net poor families, 27.1 percent receive this assistance in Massachusetts compared with 14.4 percent in Georgia and 17.9 percent in Illinois.

The receipt of the federal EITC is higher in Georgia and Illinois than in Massachusetts. Massachusetts has relatively fewer workers among its lower-income families, and it has fewer families with children that can qualify for the larger credit. As expected, families in Illinois and Massachusetts receive state EITCs at the same rate as the federal EITC. A high share (94.7 percent) of Georgia's low-income families receives the state low-income credit. 
TABLE 6. Sources of Income, 2008 (SPM Units Containing Children or Nonelderly Heads)

\begin{tabular}{|c|c|c|c|c|c|c|}
\hline & \multicolumn{3}{|c|}{ All } & \multicolumn{3}{|c|}{ Pre-Safety Net Poor ${ }^{\mathrm{a}}$} \\
\hline & GA & IL & MA & GA & IL & MA \\
\hline & \multicolumn{6}{|c|}{ Percent of SPM units with income source } \\
\hline Positive pre-safety net income ${ }^{b}$ & 94.9 & 95.6 & 95.2 & 73.2 & 73.8 & 71.8 \\
\hline Social Security & 10.2 & 8.9 & 10.1 & 22.3 & 20.8 & 23.6 \\
\hline Unemployment compensation & 6.7 & 9.7 & 10.1 & 8.3 & 10.1 & 10.5 \\
\hline Welfare (TANF, SSF, other) & 1.4 & 1.8 & 4.2 & 5.0 & 6.6 & 18.1 \\
\hline SSI & 4.4 & 3.8 & 4.9 & 15.0 & 13.8 & 19.9 \\
\hline \multicolumn{7}{|l|}{ Near-Cash Assistance } \\
\hline SNAP & 15.3 & 15.0 & 12.2 & 61.5 & 66.4 & 55.4 \\
\hline Public/subsidized housing & 3.2 & 3.5 & 5.2 & 14.4 & 17.9 & 27.1 \\
\hline Federal EITC & 20.2 & 17.0 & 12.6 & 48.1 & 46.9 & 37.7 \\
\hline Federal refundable child tax credit & 12.7 & 11.1 & 7.6 & 20.1 & 20.9 & 15.6 \\
\hline \multirow[t]{2}{*}{ State EITC/Georgia Low Income Credit } & 31.3 & 17.0 & 12.6 & 94.7 & 46.9 & 37.7 \\
\hline & \multicolumn{6}{|c|}{ Average income amount if received ${ }^{c}$} \\
\hline Positive pre-safety net income ${ }^{b}$ & 69,414 & 78,558 & 89,646 & 10,314 & 10,810 & 10,680 \\
\hline \multicolumn{7}{|l|}{ Cash Assistance } \\
\hline Social Security & 11,738 & 12,497 & 12,038 & 11,261 & 12,435 & 11,639 \\
\hline Unemployment compensation & 3,815 & 4,696 & 6,094 & 3,330 & 3,852 & 4,464 \\
\hline Welfare (TANF, SSF, other) & 2,640 & 3,082 & 4,698 & 2,510 & 2,950 & 4,750 \\
\hline SSI & 5,909 & 6,392 & 6,944 & 6,423 & 6,956 & 7,409 \\
\hline \multicolumn{7}{|l|}{ Near-Cash Assistance } \\
\hline SNAP & 2,405 & 2,434 & 1,972 & 2,759 & 2,856 & 2,247 \\
\hline Public/subsidized housing & 4,653 & 5,197 & 5,438 & 5,169 & 5,747 & 5,848 \\
\hline Federal EITC & 1,876 & 1,869 & 1,668 & 2,081 & 2,135 & 1,882 \\
\hline Federal refundable child tax credit & 1,247 & 1,246 & 1,185 & 1,088 & 1,144 & 1,201 \\
\hline State EITC/Georgia Low Income Credit & 31 & 93 & 250 & 40 & 107 & 282 \\
\hline \multicolumn{7}{|c|}{ ource: TRIM3 using 2008 American Community Survey. } \\
\hline \multicolumn{7}{|c|}{ Units with pre-safety net income lower than the SPM poverty threshold. } \\
\hline \multicolumn{7}{|c|}{$\begin{array}{l}\text { b. Pre-safety net income includes cash income before cash and noncash government benefits and tax credits. Workers compensation and veterans } \\
\text { benefits are included in pre-safety net income because they are reported as other income on the ACS. }\end{array}$} \\
\hline
\end{tabular}

The average benefits received by those enrolled also reflect program rules and the states' economic characteristics. Average Social Security benefits for all families range from $\$ 11,738$ in Georgia to $\$ 12,497$ in Illinois. Social Security benefits reflect family composition (whether they are primarily single adults or families) and earnings histories among those qualifying. Average unemployment insurance, welfare, and SSI benefits are highest in Massachusetts and lowest in Georgia, with Illinois falling in the middle. SNAP benefits are somewhat lower in Massachusetts than in the other states ( $\$ 2,247$ for pre-safety net poor families compared with $\$ 2,759$ and $\$ 2,856$, respectively, in Georgia and Illinois). In contrast, the value of the housing assistance benefit is highest in Massachusetts, reflecting its higher fair-market rents. The average value of 
the EITC is lowest in Massachusetts, probably reflecting relatively fewer full-time workers, families with children, and smaller family sizes as discussed earlier. The value of the EITC (and other safety net benefits) also reflects the incomes of enrollees, and enrollees with lower incomes generally receive higher benefits.

\section{Summary}

The characteristics of the three focal states' populations differ in some important ways, although differences are not dramatic. Massachusetts has somewhat smaller family sizes, fewer full-time workers, and more individuals in families without children. Approximately a quarter of Georgia's families and pretransfer poor families live in rural areas, compared with less than 2 percent in Massachusetts. About 19 percent of nonelderly families in Georgia and 17 percent in Illinois and Massachusetts have private (pre-safety net) incomes below the SPM poverty threshold. States' safety net policies vary in expected directions with Georgia providing the lowest benefits in programs determined by state policy and Massachusetts providing the highest benefits. These policies, as well as families' economic positions and the extent of participation in safety net programs, determine the overall level of benefits in each state.

\section{Poverty across the Focal States}

The differences in states' population characteristics and safety net policies affect their poverty profiles. Using the official poverty definition, the poverty rate among children is 10.5 percent in Massachusetts, nearly half the 19.3 percent rate in Georgia (table 7). Since the official poverty measure uses fixed thresholds

TABLE 7. Variation in Poverty by Definition, 2008

\begin{tabular}{|c|c|c|c|c|}
\hline & $\begin{array}{l}\text { Population } \\
\text { (thousands) }\end{array}$ & $\begin{array}{c}\text { Official } \\
\text { poverty rate }\end{array}$ & $\begin{array}{c}\text { SPM without } \\
\text { geographic adjustment }\end{array}$ & $\begin{array}{c}\text { SPM with } \\
\text { geographic adjustment }\end{array}$ \\
\hline \multicolumn{5}{|c|}{ All (in units with children or nonelderly heads) } \\
\hline GA & 8,558 & 14.1 & 15.2 & 12.9 \\
\hline IL & 11,154 & 11.8 & 11.5 & 11.2 \\
\hline MA & 5,506 & 8.8 & 6.9 & 9.4 \\
\hline \multicolumn{5}{|c|}{ Children } \\
\hline GA & 2,540 & 19.3 & 16.7 & 13.8 \\
\hline IL & 3,173 & 16.4 & 12.7 & 12.4 \\
\hline MA & 1,430 & 10.5 & 5.4 & 9.0 \\
\hline \multicolumn{5}{|c|}{ Adults (in units with children or nonelderly heads) } \\
\hline GA & 6,018 & 12.0 & 14.5 & 12.5 \\
\hline IL & 7,982 & 10.0 & 11.1 & 10.7 \\
\hline MA & 4,076 & 8.1 & 7.4 & 9.6 \\
\hline \multicolumn{5}{|c|}{ Adults living with children } \\
\hline GA & 2,739 & 12.6 & 13.0 & 10.5 \\
\hline IL & 3,608 & 11.0 & 9.9 & 9.7 \\
\hline MA & 1,697 & 7.0 & 4.4 & 7.3 \\
\hline \multicolumn{5}{|c|}{ Adults living without children } \\
\hline GA & 3,279 & 11.4 & 15.8 & 14.2 \\
\hline IL & 4,373 & 9.3 & 12.0 & 11.5 \\
\hline MA & 2,379 & 8.9 & 9.5 & 11.2 \\
\hline
\end{tabular}

Source: TRIM3 using 2008 American Community Survey. 
across states, the relatively higher cost of housing in Massachusetts does not affect these results. Also, the official poverty measure only includes cash income, and cash safety net benefits tend to be highest in Massachusetts and lowest in Georgia. The official poverty rate differences across the states are not as dramatic for adults, especially those living without children, although they follow the same pattern as for children. States' safety net policies tend to target families with children.

The SPM before geographic adjustment in the thresholds reduces child poverty rates since all the safety net benefits are counted. The effect is most dramatic in Massachusetts where the child poverty rate drops from 10.5 to 5.4 percent. The child poverty rate in Illinois drops from 16.4 to 12.7 percent, and Georgia's child poverty rate drops from 19.3 to 16.7 percent. The effect for adults is mixed. Poverty increases from 12.0 to 14.5 percent in Georgia and from 10.0 to 11.1 percent in Illinois. The Massachusetts adult poverty rate, in contrast, drops slightly from 8.1 to 7.4 percent, reflecting the state's relatively generous UI and SSI policies that target adults. The SPM rates reflect differences in not just safety net benefits but also taxes and work expenses. They also reflect thresholds that include out-of-pocket medical expenses that are higher on average for adults than children. Taxes and necessary expenses tend to increase the SPM among adults.

The SPM with geographic adjustment changes the state poverty differentials. Compared with the SPM without the geographic adjustment, child poverty in Georgia drops from 16.7 to 13.8 percent, decreases slightly in Illinois from 12.7 to 12.4 percent, and increases from 5.4 to 9.0 percent in Massachusetts. Similarly, the SPM with geographic adjustment for adults decreases in Georgia, decreases slightly in Illinois, and increases in Massachusetts compared with the SPM without this adjustment. The relatively high cost of housing in Massachusetts means that families need more resources to rise above the SPM thresholds.

\section{Summary}

The SPM thresholds produce substantially different poverty rates than the official poverty rate. Since the SPM accounts for all government benefits and necessary expenses (for taxes, child care, out-of-pocket medical costs, and work expenses), families with more government benefits will tend to be less poor and those with higher expenses more poor than shown by the official poverty measure. Also, lower housing-cost states have lower SPM thresholds than higher housing-cost states. Moving from the official poverty rates to the SPM without its geographic adjustment reduces poverty among children (since many benefit programs benefit them) but increases poverty among adults (since many have high necessary expenses). Adding the SPM geographic adjustment reduces poverty rates in Georgia and causes a slight reduction in poverty rates in Illinois but increases poverty in Massachusetts for both children and adults, reflecting high housing costs in Massachusetts.

\section{How Safety Net Policies Affect the SPM}

The SPM poverty rates would be much higher in all three states without safety net benefits. Eliminating all public benefits would increase adult poverty by 7 percentage points or more-to 20.6 percent in Georgia, 17.8 percent in Illinois, and 16.2 percent in Massachusetts (figure 1a).${ }^{10}$ Child poverty would at least double in all three states in the absence of safety net programs (figure 1b). Poverty rates would increase from 13.8 to 28.7 percent in Georgia, from 12.4 to 24.6 percent in Illinois, and from 9.0 to 21.0 percent in Massachusetts without federal and state benefit programs. The universal benefits (Social Security and UI) have relatively small effects on SPM poverty rates for the nonelderly population (about 3 percentage points for adults and 2 points for children); the means-tested programs account for most of the poverty reduction. 
FIGURE 1a. Effects of Safety Net on SPM Poverty Rate: Adults, 2008

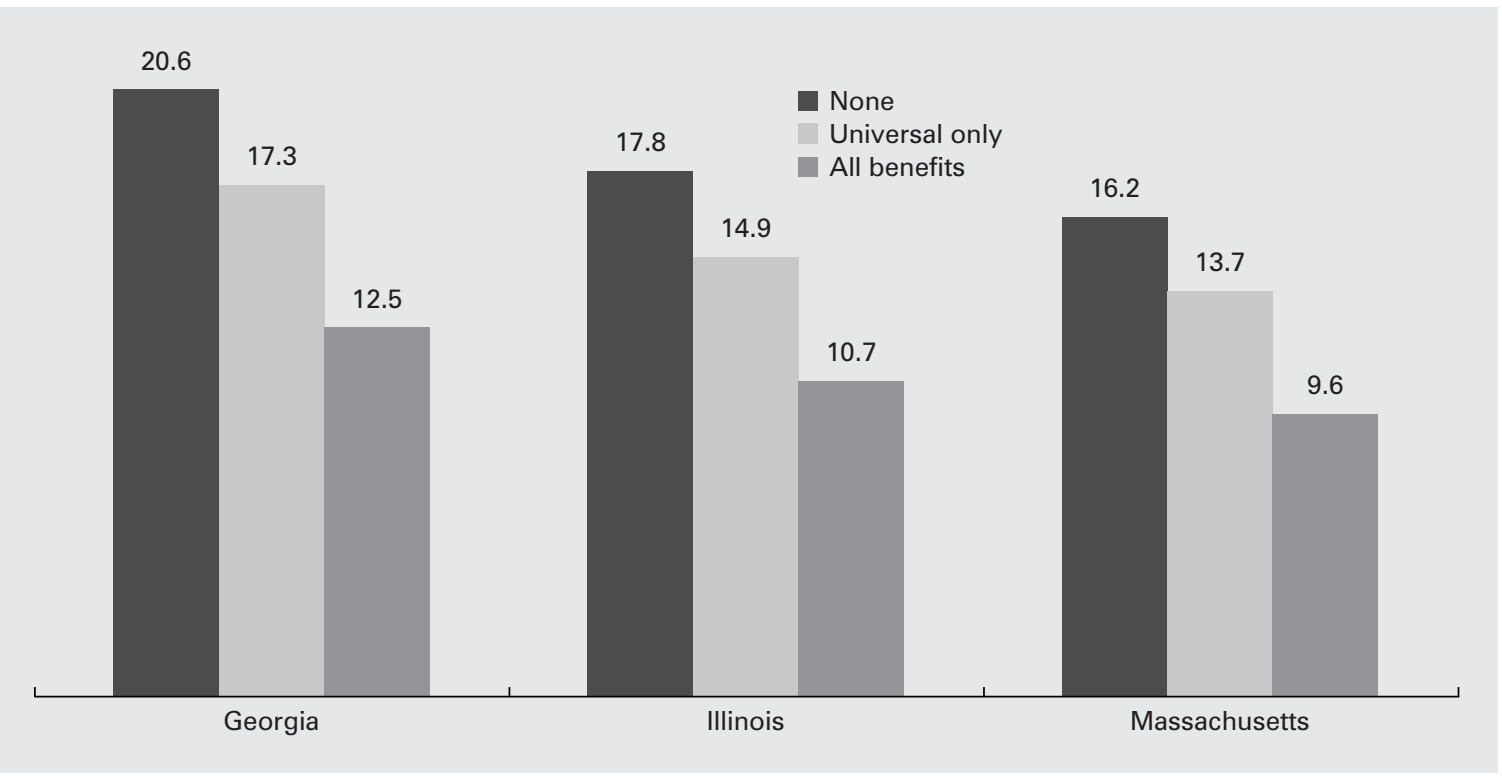

Source: TRIM3 using 2008 American Community Survey.

Note: Rates for adults are for all adults in families with children or nonelderly heads.

FIGURE 1b. Effects of Safety Net on SPM Poverty Rate: Children under 18, 2008

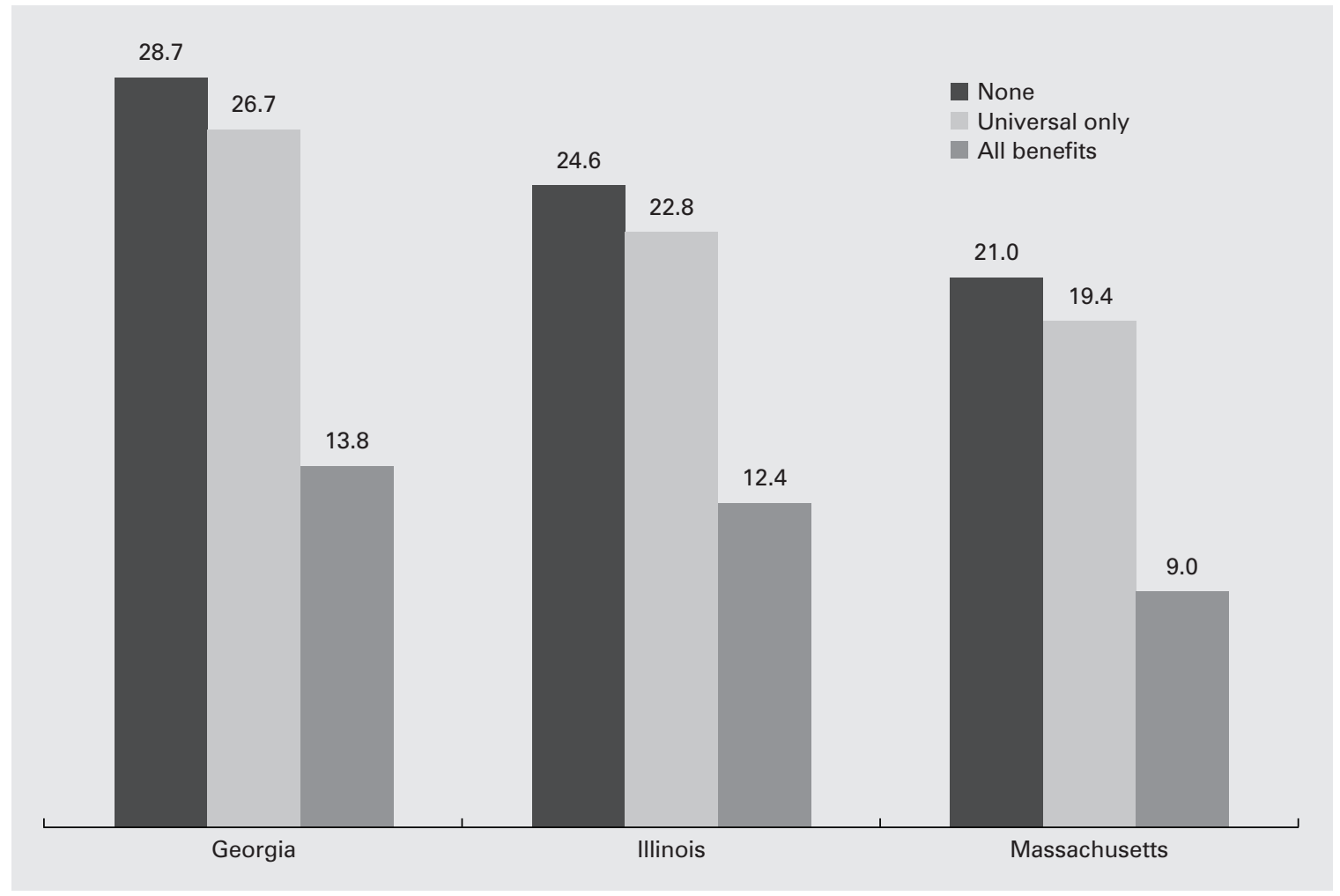

Source: TRIM3 using 2008 American Community Survey. 
Individual elements of the safety net have different effects on poverty that vary for adults and children (figure 2). Social Security has a larger effect on adult poverty reduction since many older adults do not have children living at home and can qualify for disability and surviving spouse benefits without having child dependents. Social Security also reduces poverty more among adults in Georgia than in Illinois or Massachusetts (3.2 percentage points compared with 2.7 and 2.5 percentage points) since benefits are set nationally and the poverty thresholds in Georgia, on average, are the lowest among the three states. Unemployment insurance is more effective in reducing poverty among children than among adults, likely reflecting the high probability of having children in families with unemployed adults. Benefits reduce the SPM more in Massachusetts and Illinois than in Georgia, reflecting higher UI benefit payments in these states.

The effects of some individual elements of states' means-tested programs on SPM rates show substantial differences across the three focal states (figures $3 \mathrm{a}$ and $\mathrm{b}$ ). Massachusetts's relatively generous TANF program reduces the SPM rate among adults by 0.5 points and among children by 1.9 points, but TANF has only minimal effects on poverty in the other states. ${ }^{11} \mathrm{SNAP}$, in contrast, produces similar reductions in the SPM for adults in the three states (from 1.3 to 1.6 percentage points). The effects for children are much larger. SNAP reduces the SPM rate by 5.1 percentage points in Georgia, 4 points in Illinois, and 3.4 points in Massachusetts. SNAP provides a national benefit and, as shown earlier, more families receive benefits and the benefits are higher in Georgia and Illinois than in Massachusetts.

FIGURE 2. Effects of Universal Programs on SPM Poverty Rates, 2008

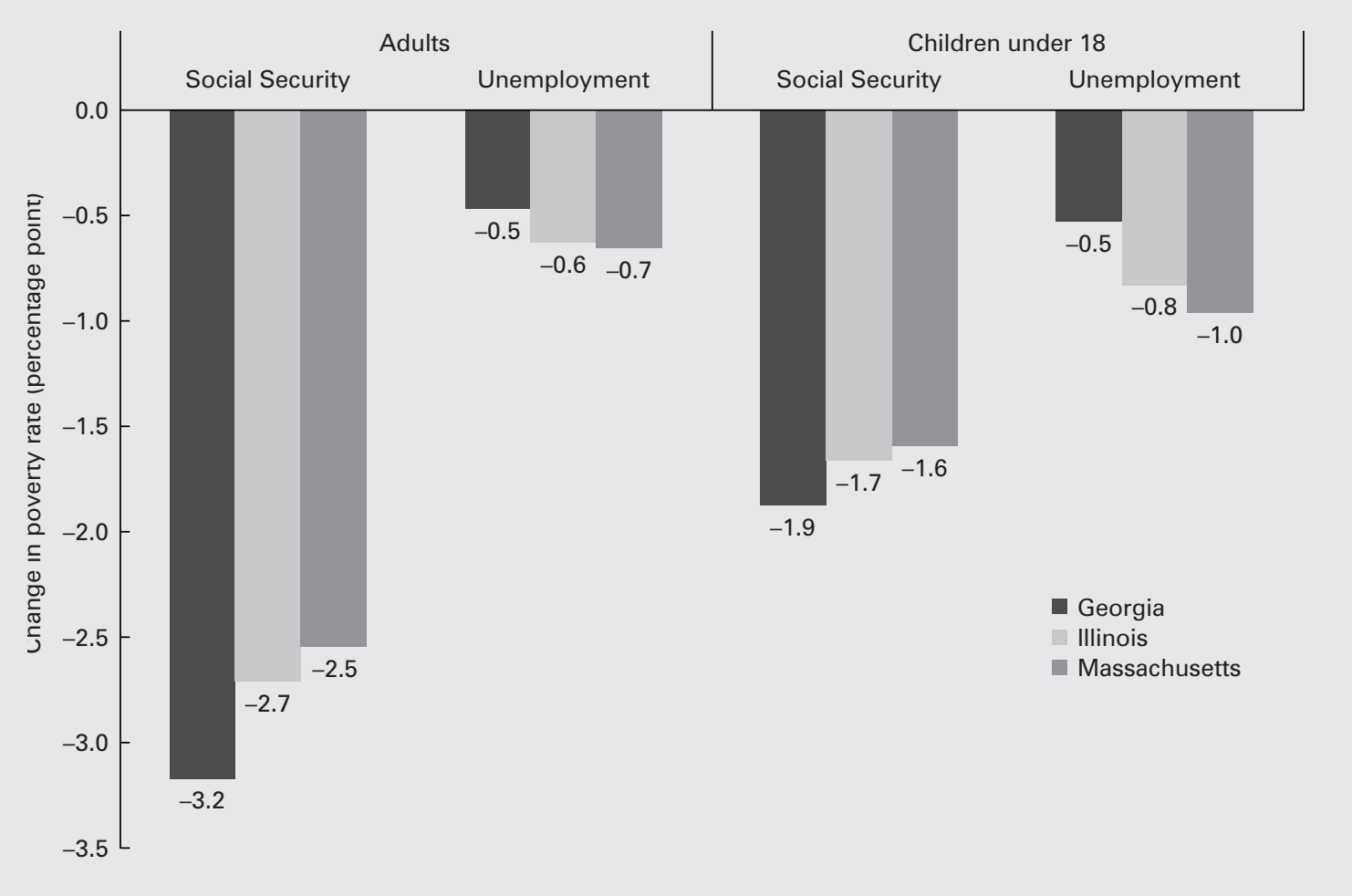

Source: TRIM3 using 2008 American Community Survey.

Note: Rates for adults are for all adults in families with children or nonelderly heads. 
FIGURE 3a. Effects of Selected Safety Net Programs on SPM Poverty Rates: Adults, 2008

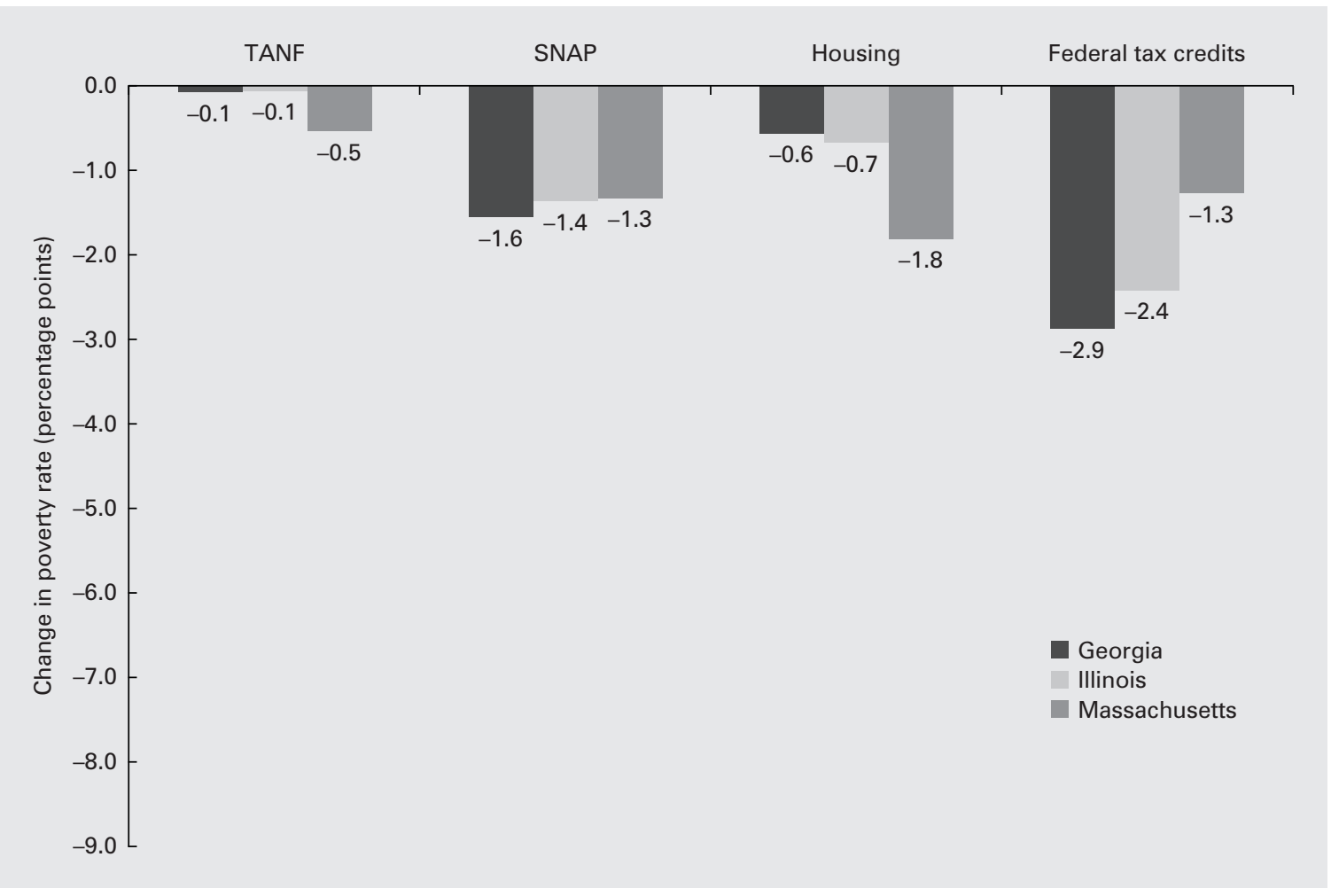

Source: TRIM3 using 2008 American Community Survey.

Note: Rates for adults are for all adults in families with children or nonelderly heads.

FIGURE 3b. Effects of Selected Safety Net Programs on SPM Poverty Rates: Children under 18, 2008

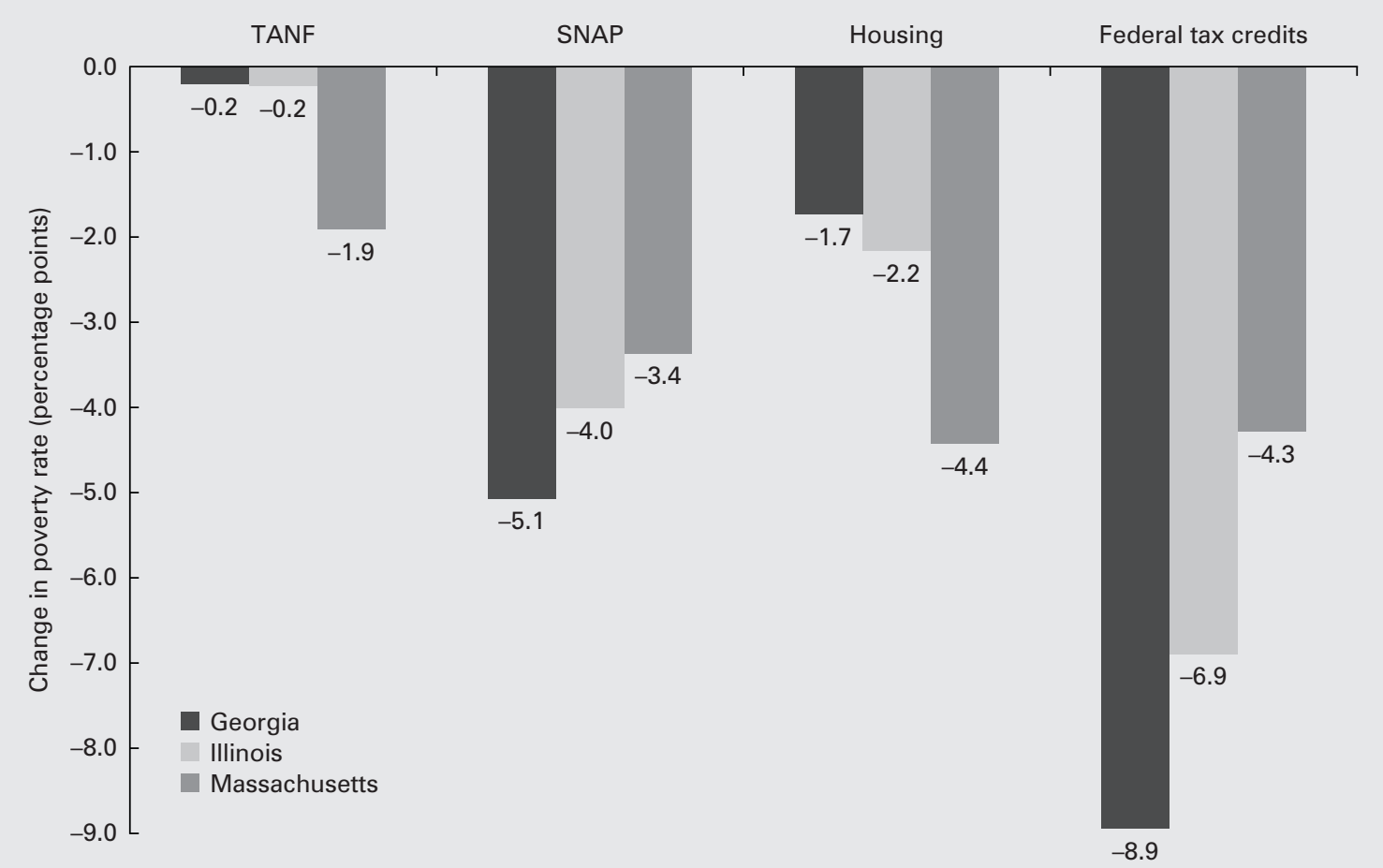

Source: TRIM3 using 2008 American Community Survey. 
Housing assistance reflects its unique program parameters. Massachusetts has more vouchers to distribute relative to its population size, and the vouchers are valued at their higher housing prices. Housing assistance reduces the child SPM rate in Massachusetts by 4.4 percentage points, but only 1.7 points in Georgia and 2.2 points in Illinois. Finally, federal tax credits (combining the effects of the EITC and child credit) reflect the pattern seen with other federal programs that provide the same benefit to families with the same income and number of children regardless of where they live. In short, the geographic variations in the SPM thresholds mean that federal benefits with fixed benefit values across the country have a greater effect on poverty reduction in states with lower housing costs than in states with higher housing costs. Federal tax credits reduce the SPM for children more than any other safety net programs in Georgia and Illinois. In contrast, housing assistance has about the same effect on the SPM in Massachusetts as federal tax credits. (The more detailed table in appendix $\mathrm{C}$ shows the effects of all safety net programs examined in this analysis on the SPM.)

\section{Effects on the SPM Distribution}

Of course, safety net policies affect families across the distribution of poverty (as measured by the SPM). Some families move out of deep poverty and closer to the poverty threshold even though they do not move all the way above the threshold. Since the SPM takes into account taxes paid and necessary expenses, some families may move down in the SPM poverty distribution if their safety net benefits do not offset necessary expenses. States' safety net policies also affect these movements.

The safety net substantially reduces the share of families in deep poverty (below 50 percent of the threshold) (table 8). For example, in Georgia, 34 percent of adults in deep poverty before safety net benefits remain in deep poverty, 45 percent move to the 50-100 percent of poverty category, and 21 percent move above the poverty threshold after all safety net benefits, taxes, and necessary expenses are taken into account. The shifts in poverty status among adults in Illinois are similar, with 31 percent remaining in deep poverty and 21 percent moving above poverty. In Massachusetts, 30 percent of adults in deep poverty based on their pre-safety net income move above the poverty threshold.

Poverty reduction is more dramatic for children in deep poverty before safety net benefits. Only 21 percent remain in deep poverty in Georgia, along with 17 percent in Illinois and 12 percent in Massachusetts. Pre- and post-safety net SPM poverty rates illustrate the differences in states' safety net policies. In Massachusetts, 41 percent of children in deep poverty based on their families' private incomes move out of poverty, compared with only 20 percent in Georgia and 18 percent in Illinois.

The differences across states are smaller for families with pre-safety net incomes between 50 and 100 percent of the SPM. Just over half the adults and about 40 percent of the children remain in this category after all benefits and tax policies are taken into account in all three states. About 45 percent of adults and 60 to 62 percent of children in this pre-safety net income group move above the poverty threshold. While the results illustrate the effectiveness of the safety programs in reducing poverty, they also illustrate similar effects across the three states for families closer to the SPM thresholds. The national benefit policies can moderate the effects of more minimal state safety net policies if housing costs (and therefore SPM thresholds) are also lower.

These results also illustrate that tax policies and necessary expenses can strain the incomes of low-income families with pre-safety net incomes above the SPM. For example, 16 to 18 percent of adults with private incomes between 100 and 150 percent of the SPM end up with income below the SPM threshold 
TABLE 8. SPM Poverty Pre- and Post-Safety Net, 2008

\begin{tabular}{|c|c|c|c|c|c|c|c|c|c|c|c|}
\hline & \multirow[b]{2}{*}{ Post: } & \multicolumn{5}{|c|}{ Adults $^{\mathrm{a}}$} & \multicolumn{5}{|c|}{ Children } \\
\hline & & $<50 \%$ & $\begin{array}{c}50< \\
100 \%\end{array}$ & $\begin{array}{l}100< \\
150 \%\end{array}$ & $\begin{array}{l}150< \\
200 \%\end{array}$ & $200 \%+$ & $<50 \%$ & $\begin{array}{c}50< \\
100 \%\end{array}$ & $\begin{array}{l}100< \\
150 \%\end{array}$ & $\begin{array}{l}150< \\
200 \%\end{array}$ & $200 \%+$ \\
\hline \multicolumn{12}{|l|}{ Georgia } \\
\hline \multicolumn{12}{|l|}{ Pre: } \\
\hline$<50 \%$ & & 34.1 & 44.8 & 16.7 & 3.3 & 1.1 & 20.7 & 59.0 & 19.4 & 0.6 & 0.3 \\
\hline $50<100 \%$ & & 3.3 & 51.6 & 37.0 & 5.6 & 2.4 & 0.0 & 39.4 & 57.0 & 3.1 & 0.5 \\
\hline $100<150 \%$ & & 0.0 & 17.4 & 67.4 & 11.4 & 3.8 & 0.0 & 6.8 & 83.3 & 8.9 & 1.0 \\
\hline $150<200 \%$ & & 0.0 & 0.0 & 50.2 & 43.0 & 6.8 & 0.0 & 0.0 & 41.6 & 56.1 & 2.3 \\
\hline $200 \%+$ & & 0.0 & 0.0 & 0.2 & 13.6 & 86.2 & 0.0 & 0.0 & 0.3 & 17.4 & 82.3 \\
\hline \multicolumn{12}{|l|}{ Illinois } \\
\hline \multicolumn{12}{|l|}{ Pre: } \\
\hline$<50 \%$ & & 31.0 & 48.1 & 16.9 & 3.1 & 0.9 & 17.0 & 65.1 & 17.3 & 0.6 & 0.0 \\
\hline $50<100 \%$ & & 3.0 & 50.7 & 37.7 & 6.6 & 2.1 & 0.1 & 39.7 & 57.0 & 3.0 & 0.3 \\
\hline $100<150 \%$ & & 0.0 & 16.1 & 68.1 & 11.2 & 4.6 & 0.0 & 7.3 & 82.5 & 9.4 & 0.8 \\
\hline $150<200 \%$ & & 0.0 & 0.1 & 46.1 & 44.3 & 9.6 & 0.0 & 0.3 & 40.6 & 54.0 & 5.1 \\
\hline $200 \%+$ & & 0.0 & 0.0 & 0.1 & 10.8 & 89.1 & 0.0 & 0.0 & 0.4 & 13.6 & 86.1 \\
\hline \multicolumn{12}{|l|}{ Massachusetts } \\
\hline \multicolumn{12}{|l|}{ Pre: } \\
\hline$<50 \%$ & & 33.6 & 36.1 & 28.1 & 1.9 & 0.4 & 12.1 & 47.3 & 39.9 & 0.7 & 0.0 \\
\hline $50<100 \%$ & & 3.9 & 51.1 & 35.6 & 7.5 & 2.0 & 0.1 & 38.0 & 57.6 & 3.8 & 0.5 \\
\hline $100<150 \%$ & & 0.0 & 17.6 & 64.3 & 14.0 & 4.0 & 0.0 & 8.5 & 78.2 & 12.2 & 1.1 \\
\hline $150<200 \%$ & & 0.0 & 0.0 & 50.5 & 39.4 & 10.1 & 0.0 & 0.0 & 44.6 & 51.6 & 3.8 \\
\hline $200 \%+$ & & 0.0 & 0.0 & 0.1 & 10.8 & 89.1 & 0.0 & 0.0 & 0.2 & 13.9 & 85.9 \\
\hline
\end{tabular}

Source: TRIM3 using 2008 American Community Survey.

a. Adults in units with children or nonelderly heads.

in these three states. This effect is smaller for children, because more of these families qualify for the federal EITC or child tax credit, credits designed to offset taxes at these low income levels. About four-fifths of children living in families with incomes between 100 and 150 percent of the SPM threshold remain there after taking into account all safety net benefits, taxes, and necessary expenses.

\section{Dissecting the SPM}

The calculations behind the SPM poverty rate measurement are illustrated in table 9 for families with children (tables in appendix $\mathrm{C}$ show the calculations for all families with children or nonelderly heads). The majority of families with children that start out with private income less than the SPM threshold remain poor in Georgia and Illinois (61 percent). However, the Massachusetts safety net policies move a much larger share of these families above the SPM threshold (51 percent) even though those removed from poverty begin with lower private incomes, on average, than the families lifted above the SPM thresholds in the other two states.

The calculations for families that remain poor after all safety net benefits are taken into account show that these families started out with less private income than those that move above poverty in all three 
TABLE 9. Safety Net Effects on Family Income for Families with Children, 2008

\begin{tabular}{|c|c|c|c|c|c|c|}
\hline & \multicolumn{3}{|c|}{ Remaining in Poverty } & \multicolumn{3}{|c|}{ Lifted above Poverty } \\
\hline & GA & IL & MA & GA & IL & MA \\
\hline Number of families & 149,762 & 170,232 & 61,927 & 97,766 & 109,926 & 63,846 \\
\hline Percent of pre-safety net poor & 60.5 & 60.8 & 49.2 & 39.5 & 39.2 & 50.8 \\
\hline Private income & 8,961 & 9,766 & 11,561 & 15,803 & 17,055 & 14,386 \\
\hline \multicolumn{7}{|l|}{ Average amount received (\$) } \\
\hline Social Security & 1,113 & 922 & 1,252 & 3,832 & 3,951 & 3,767 \\
\hline Unemployment & 237 & 321 & 470 & 496 & 1,019 & 847 \\
\hline Welfare & 180 & 330 & 1,875 & 295 & 307 & 2,611 \\
\hline SSI & 845 & 894 & 1,212 & 1,627 & 1,334 & 2,355 \\
\hline SNAP & 3,940 & 4,289 & 2,720 & 2,630 & 2,655 & 2,399 \\
\hline Public/subsidized housing & 1,344 & 1,718 & 2,107 & 1,473 & 1,894 & 4,203 \\
\hline EITC & 1,770 & 1,873 & 1,685 & 3,026 & 2,945 & 2,163 \\
\hline Refundable child tax credit & 326 & 361 & 504 & 851 & 939 & 598 \\
\hline State tax credits & 62 & 94 & 253 & 39 & 147 & 324 \\
\hline Gross income (\$) & 18,777 & 20,566 & 23,639 & 30,071 & 32,247 & 33,652 \\
\hline - Taxes & -719 & -869 & -975 & $-1,273$ & $-1,493$ & $-1,168$ \\
\hline -Work expenses & $-1,195$ & $-1,255$ & $-1,326$ & $-1,547$ & $-1,605$ & $-1,522$ \\
\hline Net income (\$) & 16,864 & 18,442 & 21,337 & 27,251 & 29,148 & 30,962 \\
\hline
\end{tabular}

Source: TRIM3 using 2008 American Community Survey.

states. Families' success in moving out of poverty to a large extent reflects their starting positions. Nonetheless, safety net policies also figure very importantly in individual families' economic positions. In Georgia, families with children lifted above the SPM threshold start out with average private income of $\$ 15,803$ and end up with $\$ 27,251$ in average net income (72 percent higher) (table 9). ${ }^{12}$ The increase for those moving above the SPM threshold is 71 percent in Illinois and 115 percent in Massachusetts. With SNAP as one important exception, the safety net benefits received by those lifted above poverty are higher, on average, than benefits received by those remaining poor despite their relatively higher starting income position. (The averages reflect both the shares receiving the benefits and the benefits received.) Social Security benefits and unemployment benefits are higher. Again, welfare and public housing benefits stand out in Massachusetts as substantially higher, especially among those moving above the SPM threshold. The higher SNAP benefits for families remaining below the SPM threshold are likely attributable to the lower private income and cash transfers received by these families, which make them eligible for higher SNAP benefit amounts. Families remaining below the SPM threshold may also be larger on average with higher SNAP benefits but also higher SPM thresholds.

\section{Summary}

This analysis illustrates that a more modern measure of poverty is required to assess the antipoverty effectiveness of the safety net. The SPM includes the effects of all cash and noncash benefits, as well as refundable tax credits. It deducts necessary expenses (taxes, child care, and work expenses). Unlike the official 
poverty measure, the SPM takes into account differences in the cost of housing across states. The SPM shows that the safety net dramatically reduces poverty, especially among children. SPM geographic adjustments also shift the poverty profile across states, reducing poverty rates for adults and children in Georgia, causing a slight reduction in poverty rates in Illinois, and increasing poverty rates in Massachusetts, reflecting these states' relatively low, moderate, and high housing costs.

An assessment of safety net policies using the SPM highlights some unique features of different programs. Federal programs with benefits that do not vary across states such as SNAP and the EITC have a larger impact in states with lower housing costs and therefore lower poverty thresholds. States with relatively generous safety net policies and higher-than-average housing costs can moderate some effects of higher living costs on poverty.

Some specific findings:

- Poverty among children as measured by the SPM would at least double in all three states in the absence of safety net benefits. Means-tested programs have much greater poverty-reduction power for children and nonelderly adults than universal programs that do not target the poor.

- SNAP benefits alone reduce the SPM by 5.1 percentage points among children in Georgia, 4 points in Illinois, and 3.4 points in Massachusetts. These effects reflect differences in program participation rates but also the higher relative value of SNAP in lower-cost states such as Georgia and Illinois.

- Housing assistance is especially effective in reducing the number of families falling below the SPM threshold in higher-cost states since its value varies with housing costs. However, housing assistance is not an entitlement and is received by only 14 percent of the pre-safety net poor in Georgia, 18 percent in Illinois, and 27 percent in Massachusetts.

- Refundable federal tax credits have the largest poverty-reduction effects especially among families with children in Georgia and Illinois where the value of these credits goes the furthest toward increasing family resources.

- Safety net policies alleviate poverty among the majority of families in deep poverty (pre-safety net incomes below 50 percent of the SPM threshold). In all three states, at least 8 out of 10 children in deep poverty based on their private income move out of deep poverty as a result of government safety net policies.

- States' safety net policies matter. Children living in deep poverty based on pre-safety net income are twice as likely to move out of poverty in Massachusetts as in Georgia or Illinois. About 4 in 10 move out of poverty in Massachusetts as a result of the safety net, compared with about 2 in 10 in Georgia and Illinois.

The SPM allows the assessment of safety net policies across programs and states. The SPM shows that three safety net policies not taken into account in the official poverty measure-the federal EITC, SNAP, and housing assistance-have the largest effects on poverty reduction. The results demonstrate the importance of adopting the measure for any assessment of poverty status and the effects of safety net policies. It is critical to work toward making the measure available at the state level. 



\section{APPENDIX A. \\ SUPPLEMENTAL POVERTY MEASURE THRESHOLDS}

The SPM thresholds used in this analysis are based on the 2008 SPM thresholds developed by Garner (2011b) that include spending on medical out-of-pocket expenses. We adjust the housing portion of the threshold for variation in housing expenses, by state and by Super-Public Use Microdata Area (Super-PUMA) within state. The medical out-of-pocket portion of the threshold is adjusted for differences in family health insurance status, health status, and presence of an elderly member. Components of the SPM threshold are explained in greater detail below.

The 2008 SPM threshold used for this analysis is based on out-of-pocket spending for food, clothing, shelter, health care, and utilities (FCSUM), with a multiplier of 1.2 to provide for additional basic needs. The threshold is calculated using five years of Consumer Expenditure Survey data and reflects FCSUM spending at the 33rd percentile for families with two children. The threshold is adjusted for families of different size and number of children using a three-parameter equivalence scale. The thresholds are also adjusted to reflect differences in housing costs for renters, homeowners with mortgages, and homeowners without mortgages. The resulting thresholds for a family of two adults and two children for 2008 are $\$ 26,252$ for renters, $\$ 26,660$ for owners with mortgages, and $\$ 21,860$ for owners without mortgages.

Prior estimates of the SPM thresholds (Garner 2010, 2011a) did not include an allowance for outof-pocket medical expenses (MOOP). Based on National Academy of Sciences (Citro and Michael 1995) and the Interagency Technical Working Group (ITWG) recommendations, the Census Bureau SPM estimates subtract MOOP reported in the CPS Annual Social and Economic Supplement data from resources when calculating the SPM. Since the ACS data used for our analysis do not include MOOP, we requested a version of the SPM thresholds that includes an allowance for out-of-pocket medical 
expenses from the BLS (Garner 2011b). We adjust the MOOP share of the threshold for differences in insurance status (private, public, uninsured), elderly/nonelderly status, health status, and family size following the Census Bureau's NAS estimate methodology (Short 2001).

We develop geographic adjustments following procedures developed at the Census Bureau. Development at the Census Bureau is ongoing, and our approach most closely resembles the approach outlined in Short and Renwick (2010). ${ }^{13}$ As in that paper, our geographic adjustments are calculated based on three-year American Community Survey (ACS) estimates of median gross rents for two-bedroom rental units with complete kitchen and plumbing facilities. ${ }^{14}$ Since MSAs are not identified in the public-use ACS, we could not follow the Census Bureau's approach of adjusting the SPM by identifiable metropolitan statistical area (MSA), nonmetropolitan area, and residual metropolitan area within each state. Instead, we follow the Census Bureau methodology for calculating geographic adjustments, but calculate the adjustments at the Super-PUMA level instead of the MSA level..${ }^{15}$ We divide the median rents calculated for each Super-PUMA by the national median to calculate an initial index. We normalize the index so the mean of the resulting indices (when applied to all persons) is equal to one. We then multiply the housing portion ${ }^{16}$ of the SPM threshold by the normalized index, and add in the nonhousing portion and MOOP adjustment to calculate the final threshold.

Table A1 shows the geographic adjustments for each state, by Super-PUMA, and the resulting threshold for a two-adult, two-child family that rents its home, has private insurance, and is in good health. Thresholds for the example family range from $\$ 22,503$ to $\$ 27,449$ in Georgia, from $\$ 21,763$ to $\$ 29,964$ in Illinois, and from $\$ 25,200$ to $\$ 34,575$ in Massachusetts. State maps showing the boundaries of each 2000 Super-PUMA area can be accessed at the Census Bureau web site at http://www.census.gov/geo/ www/maps/sup_puma.htm. 
TABLE A1. Geographic Adjustments and Example Thresholds, by State and Super-PUMA

\begin{tabular}{|c|c|c|c|c|c|c|c|c|}
\hline \multicolumn{3}{|c|}{ Georgia } & \multicolumn{3}{|c|}{ Illinois } & \multicolumn{3}{|c|}{ Massachusetts } \\
\hline $\begin{array}{l}\text { Super- } \\
\text { PUMA }\end{array}$ & $\begin{array}{l}\text { Geographic } \\
\text { adjustment }\end{array}$ & $\begin{array}{l}\text { Example } \\
\text { threshold }\end{array}$ & $\begin{array}{l}\text { Super- } \\
\text { PUMA }\end{array}$ & $\begin{array}{l}\text { Geographic } \\
\text { adjustment }\end{array}$ & $\begin{array}{l}\text { Example } \\
\text { threshold }\end{array}$ & $\begin{array}{l}\text { Super- } \\
\text { PUMA }\end{array}$ & $\begin{array}{l}\text { Geographic } \\
\text { adjustment }\end{array}$ & $\begin{array}{l}\text { Example } \\
\text { threshold }\end{array}$ \\
\hline 13010 & 0.68957 & 22,503 & 17010 & 0.69419 & 22,559 & 25010 & 0.95105 & 25,661 \\
\hline 13020 & 0.75204 & 23,258 & 17020 & 0.63634 & 21,860 & 25020 & 1.35946 & 30,593 \\
\hline 13030 & 0.92675 & 25,367 & 17030 & 0.62825 & 21,763 & 25030 & 1.20096 & 28,679 \\
\hline 13040 & 0.89204 & 24,948 & 17040 & 0.81915 & 24,068 & 25040 & 1.27269 & 29,545 \\
\hline 13050 & 1.07022 & 27,100 & 17050 & 0.75204 & 23,258 & 25050 & 1.66954 & 34,337 \\
\hline 13060 & 1.08757 & 27,309 & 17060 & 0.79138 & 23,733 & 25060 & 1.08179 & 27,240 \\
\hline 13070 & 1.03898 & 26,723 & 17070 & 0.80064 & 23,845 & 25070 & 0.94873 & 25,633 \\
\hline 13080 & 1.09914 & 27,449 & 17080 & 0.83303 & 24,236 & 25080 & 1.4902 & 32,172 \\
\hline 13090 & 0.94873 & 25,633 & 17090 & 1.10261 & 27,491 & 25090 & 1.43004 & 31,445 \\
\hline 13100 & 0.7208 & 22,880 & 17100 & 1.02394 & 26,541 & 25100 & 1.68921 & 34,575 \\
\hline \multirow[t]{13}{*}{13110} & 0.77171 & 23,495 & 17201 & 1.23567 & 29,098 & 25110 & 1.29699 & 29,838 \\
\hline & & & 17202 & 1.20327 & 28,707 & 25120 & 1.38839 & 30,942 \\
\hline & & & 17300 & 1.13385 & 27,868 & 25130 & 0.91287 & 25,200 \\
\hline & & & 17401 & 1.21484 & 28,846 & & & \\
\hline & & & 17402 & 1.22641 & 28,986 & & & \\
\hline & & & 17403 & 1.02162 & 26,513 & & & \\
\hline & & & 17404 & 1.01815 & 26,471 & & & \\
\hline & & & 17405 & 1.03782 & 26,709 & & & \\
\hline & & & 17501 & 1.3074 & 29,964 & & & \\
\hline & & & 17502 & 1.04129 & 26,751 & & & \\
\hline & & & 17503 & 1.06906 & 27,086 & & & \\
\hline & & & 17504 & 0.94873 & 25,633 & & & \\
\hline & & & 17505 & 0.95567 & 25,717 & & & \\
\hline
\end{tabular}

Note: Example threshold is for two-adult, two-child family that rents, has private insurance, and is in good health. 

APPENDIX B.

\section{SIMULATION PROCEDURES THAT PRODUCE THE SPM FAMILY RESOURCE MEASURE}

The analysis relies on a combination of logical edits to the American Community Survey (ACS) data and simulation procedures to add the elements required for the Supplemental Poverty Measure (SPM) family resource measure. Three types of work are required: augmenting the ACS data on demographic characteristics, adding elements of resources that are not present in the ACS data, and making adjustments to some elements of resources that are included but underreported in the ACS data (table B1).

\section{Procedures}

These procedures first require understanding the family relationships among members of ACS households. The ACS includes each person's relationship to the householder, but does not ask for inter-relationships among other individuals. That information is needed for correct modeling of government benefit and tax programs, each of which specify who must file for benefits or taxes together. For example, the filing unit for TANF includes parents and their dependent children (but does not include other members of a household), and the filing unit for income taxes is an unmarried individual or a married couple together with their dependents. Also, poverty measures define whose resources must be included in the "family." The modern measures include all family members related by blood, marriage, or adoption, foster children, and cohabiting adults. We use the IPUMS version of the ACS, developed by researchers at the University of Minnesota, for imputations of the relationships of individuals in ACS households (Ruggles et al. 2000). Subsequently, each TRIM3 simulation module uses this information and individual program rules to determine which individuals file for benefits together or pay taxes together. 
TABLE B1. TRIM3 Procedures to Calculate Family Resources for the SPM

\begin{tabular}{|c|c|}
\hline Data & $\begin{array}{l}\text { Methods } \\
\text { ACS IPUMS }\end{array}$ \\
\hline \multicolumn{2}{|l|}{ Definition of poverty units } \\
\hline Detailed family relationship data & $\begin{array}{l}\text { ACS data plus IPUMS imputations show interrelationships of individuals } \\
\text { in households. }\end{array}$ \\
\hline Foster children & Included in the primary family. \\
\hline Cohabitors & $\begin{array}{l}\text { Combines household reference person and his or her partner (and their } \\
\text { families) into the same poverty unit (ACS does not identify other } \\
\text { cohabiting couples). Weights unit using household reference per- } \\
\text { son's weight. }\end{array}$ \\
\hline Unrelated subfamilies & $\begin{array}{l}\text { Identified using IPUMS relationship imputations. (Data do not allow } \\
\text { identification of all unrelated subfamily relationships; e.g., two } \\
\text { brothers unrelated to householder.) }\end{array}$ \\
\hline College students/group quarters & Excludes all group quarters. \\
\hline \multicolumn{2}{|c|}{ Elements of resource definition not reported in ACS data } \\
\hline Taxes & $\begin{array}{l}\text { 1) Filing unit: Head of household status assigned only to unmarried } \\
\text { householder with qualifying dependents. Applies qualifying child } \\
\text { and dependent rules to first see if person can be claimed as depend- } \\
\text { ent of parent; if not, then of householder. Does not model sharing of } \\
\text { children for EITC or dependency. } \\
\text { 2) Filing behavior: Assumes all units submit return. } \\
\text { 3) Deductions: Mortgage interest set at } 80 \% \text { of mortgage payment; } \\
\text { property tax deduction taken as reported; state tax deduction } \\
\text { based on greater of state income taxes (from preliminary state tax } \\
\text { simulation) and state sales tax deduction (from IRS look-up table); } \\
\text { average charitable contributions assigned based on IRS data (by } \\
\text { AGI level and state). State taxes recalculated based on final federal } \\
\text { tax simulation. }\end{array}$ \\
\hline \multirow[t]{2}{*}{ SNAP } & $\begin{array}{l}\text { 1) Unit: Splits households containing TANF or SSI recipients into maxi- } \\
\text { mum number of units. Households with unrelated subfamilies or } \\
\text { individuals are also split into maximum units (but partners file } \\
\text { together). All other households file as entire household. }\end{array}$ \\
\hline & $\begin{array}{l}\text { 2) Eligibility and benefits: Simulated using program rules monthly; ben- } \\
\text { efits for ineligible reporters set to } 0 \text {. Additional eligibles added to eli- } \\
\text { gible reporters to reach control targets by subgroups. }\end{array}$ \\
\hline \multirow[t]{2}{*}{ Public and subsidized housing } & $\begin{array}{l}\text { 1) Randomly assign to income-eligible renters that are eligible for a } \\
\text { positive subsidy to reach control totals by income level and other } \\
\text { demographic characteristics; reported rent used for clues. Valued at } \\
\text { FMR minus household's required rental payment (maximum of } 30 \% \\
\text { of adjusted or } 10 \% \text { of gross income). }\end{array}$ \\
\hline & $\begin{array}{l}\text { 2) Housing subsidies capped at housing portion of threshold minus } \\
\text { household's required rental payment. }\end{array}$ \\
\hline \multirow[t]{2}{*}{ Work-related expenses } & $\begin{array}{l}\text { 1) Child care: TRIM3 identifies likely CCDF subsidy recipients and } \\
\text { assigns copay. SIPP-based equations impute likelihood and amount } \\
\text { of expenses for other families; aligned to targets from SIPP and } \\
\text { NSAF data. }\end{array}$ \\
\hline & $\begin{array}{l}\text { 2) Transportation: Use Census Bureau imputation methods based on } \\
\text { miles driven and cost per mile. }\end{array}$ \\
\hline
\end{tabular}


TABLE B1. TRIM3 Procedures to Calculate Family Resources for the SPM (Continued)

\begin{tabular}{|c|c|}
\hline Data & $\begin{array}{l}\text { Methods } \\
\text { ACS IPUMS }\end{array}$ \\
\hline \multicolumn{2}{|l|}{ Cash resources corrected in the ACS data } \\
\hline Earnings, asset income, Social Security & $\begin{array}{l}\text { Generally uses ACS data, but some very high SSI amounts classified as } \\
\text { Social Security }\end{array}$ \\
\hline SSI & $\begin{array}{l}\text { SSI uses TRIM3 to simulate program rules. Additional eligibles selected } \\
\text { to meet program totals. }\end{array}$ \\
\hline \multirow[t]{2}{*}{ TANF and other welfare } & $\begin{array}{l}\text { 1) The ACS includes a variable called "welfare" that includes TANF and } \\
\text { general assistance. The model first selects some of this income as } \\
\text { TANF based on a logical edit that assigns the amount as TANF if } \\
\text { there are dependent children under age } 19 \text { and if the family is suffi- } \\
\text { ciently low income to be eligible for TANF. }\end{array}$ \\
\hline & $\begin{array}{l}\text { 2) TANF (including solely state-funded benefits) is simulated based on } \\
\text { each state's program rules and is aligned so units and benefits } \\
\text { match program totals as closely as possible. }\end{array}$ \\
\hline $\begin{array}{l}\text { Unemployment insurance, child support, } \\
\text { other income }\end{array}$ & $\begin{array}{l}\text { The ACS includes an income variable called "other" that includes UI, } \\
\text { child support, and "other." UI income is predicted based on a multi- } \\
\text { nomial logit equation. UI income is augmented via simulation to } \\
\text { come closer to actual benefits. }\end{array}$ \\
\hline
\end{tabular}

Notes: Some in-kind benefits not included (WIC, LIHEAP, and school lunch). Also, child support paid not available.

Another aspect of demographic data that is incompletely reported in the ACS is immigrant status. The ACS indicates if an individual is a citizen, but (like most surveys) does not provide a person's immigrant status. Eligibility for government benefits varies by immigrant status and year of arrival. Following procedures developed by Jeffrey Passel and others, some noncitizens are identified as refugees/asylees. ${ }^{17}$ Other noncitizens are treated as legal permanent residents, although some of these are likely undocumented aliens; thus, we may assign benefits to some noncitizens who would in reality be ineligible.

Information not reported on the ACS but required for the SPM includes tax liabilities, SNAP benefits (receipt is reported), the value of residing in public and subsidized housing, and work-related expenses (child care, transportation, and other work-related expenses). Tax simulations include payroll taxes and federal and state income taxes, including tax credits. Child care expenses are modeled by first simulating subsidized child care, then imputing unsubsidized expenses to families who do not receive subsidies. Work expenses other than child care are imputed following the standard Census Bureau procedure of a flat dollar amount per week of work, with no variation across the states.

Other information included on the ACS is underreported compared with program administrative data. It is important for the analysis of safety net programs to capture all benefits and spending, especially in the largest programs in 2008. As shown, the TRIM3 model corrects for SSI, TANF, and unemployment insurance (UI) benefit underreporting.

Unemployment insurance is important for poverty measurement but is not reported separately in the ACS data. Instead, the ACS asks respondents to report all "other income" - including unemployment benefits, child support, workers compensation, veterans benefits, and alimony. In order to use this information, we first predict the share of other income likely to be UI and likely to be child support income using regression techniques. ${ }^{18}$ Because these methods suggest that UI benefits are substantially underreported, additional benefits are simulated to come closer to actual data. 
Similarly, TANF is reported with other types of welfare in the state (such as General Assistance). We use a logical edit to assign welfare as TANF if the family has dependent children and passes the eligibility tests in its state; otherwise, the reported amount is considered "other welfare." SSI is reported separately in the ACS data, but many reported amounts appear to exceed the maximum possible annual SSI benefit, suggesting confusion with Social Security. A logical edit reassigns some reported SSI amounts as Social Security.

After any initial assignments and logical edits, the same general procedures are used to simulate all the government benefit programs - unemployment benefits, SSI, TANF, SNAP, housing assistance, and child care subsidies. In each case, TRIM3 first estimates eligibility and potential benefits using detailed national and state policies, then selects additional recipients from among the eligible individuals or families who did not already report the benefit. The selection of the caseload is made in such a way that the simulated caseload comes acceptably close to the actual caseload in terms of overall size and key characteristics. All simulations use the policies that were in effect in 2008.

A key feature of the simulations is their internal consistency. Each simulation's results may be used by subsequent simulations, creating a comprehensive and internally consistent picture of a family's income, benefits, and taxes. For example, SSI recipients are excluded from TANF assistance units; the adjusted amounts of SSI, TANF, and unemployment benefits are used in computing cash income for purposes of SNAP benefits and child care subsidies; and the rent amounts imputed by the housing simulation are used to determine the SNAP program's excess shelter deduction. All tax and benefit amounts are computed consistent with program rules and a family's detailed information; in other words, there are no "across the board" percentage adjustments to families' tax and benefit amounts in order to come closer to targets.

\section{Results}

Table B2 shows the results of these simulations for each focal state. The total units receiving benefits during the year and aggregate annual benefits come as close to the program totals shown as was feasible. It was sometimes difficult to align elements of programs because reported family characteristics prevented a better match. That is, if there are not enough families that meet program eligibility thresholds, we do not assign benefits to families that do not meet the program rules. For example, UI units fall short of administrative totals in Georgia (250,000 compared with 311,000, or 80 percent) and UI benefits received are lower than targets in all three states ( 78 percent, 74 percent, and 72 percent of program totals, respectively, in Georgia, Illinois, and Massachusetts). This means that our results underestimate the effect of this benefit on income. SSI recipients and benefits come close to program totals in all three states. Similarly, the average monthly simulated caseload for TANF matches program targets, and benefits come close to the program targets. Average annual benefits in SNAP only reach about 89 percent of target in all three states, although the simulated and actual caseload size correspond closely. Housing assistance units meet the targets in all three states. We do not have targets for the value of the housing subsidy by state.

The tax simulations compute taxes based on the federal and state rules and each tax unit's income and characteristics. While there is no alignment, the results show close comparison with program totals on total taxes paid. For example, federal income taxes (for positive returns) come within 10 to 14 percent of program totals. The model does not produce enough tax units receiving the EITC (about 72 percent in Georgia, 83 percent in Illinois, and 87 percent in Massachusetts). This is a problem often faced by tax models that rely on survey data. Even assuming 100 percent participation, not enough tax filers appear eligible for the credit. This is a complex credit with significant misfiling that is not captured in the simulation model. 


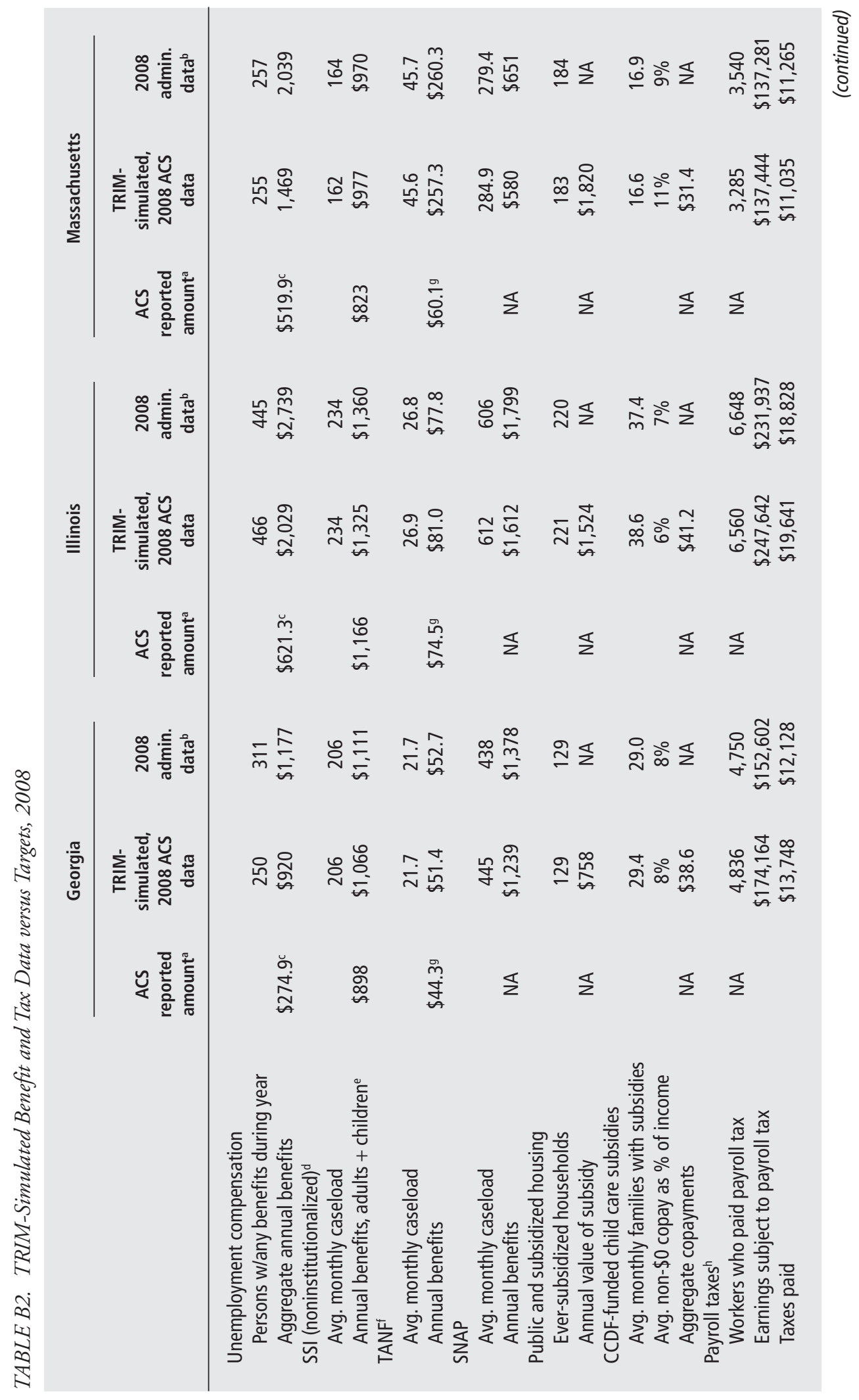




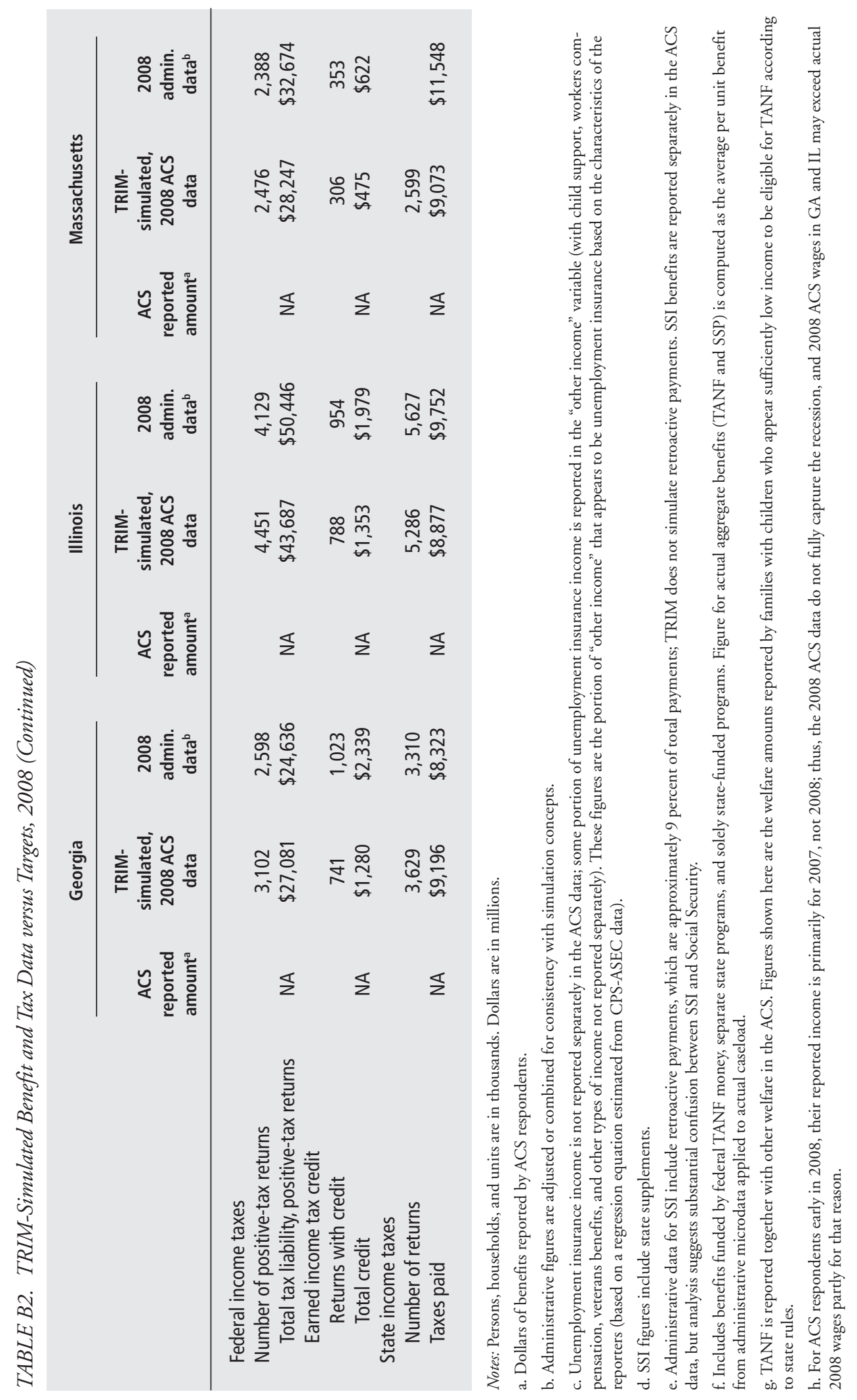

32 HOW DO STATES' SAFETY NET POLICIES AFFECT POVERTY? 


\section{APPENDIX C. \\ DETAILED SPM RESULTS FOR GEORGIA, ILLINOIS, AND MASSACHUSETTS}

C1. SPM Poverty Rate in Absence of Different Safety Net Programs, 2008

C2. Safety Net Effects on Family Income, 2008

C3. SPM Poverty Gap, Total, and in Absence of Different Safety Net Programs, 2008 
TABLE C1. SPM Poverty Rate in Absence of Different Safety Net Programs, 2008

\begin{tabular}{|c|c|c|c|c|c|c|}
\hline & \multicolumn{3}{|c|}{ Adults $^{\mathrm{a}}$} & \multicolumn{3}{|c|}{ Children } \\
\hline & GA & IL & MA & GA & IL & MA \\
\hline SPM poverty rate & 12.5 & 10.7 & 9.6 & 13.8 & 12.4 & 9.0 \\
\hline \multicolumn{7}{|l|}{ Rates without safety net benefits ${ }^{b}$} \\
\hline All public benefits & 20.6 & 17.8 & 16.2 & 28.7 & 24.6 & 21.0 \\
\hline Social Security & 15.7 & 13.4 & 12.1 & 15.7 & 14.1 & 10.6 \\
\hline Unemployment compensation & 13.0 & 11.3 & 10.2 & 14.4 & 13.2 & 10.0 \\
\hline All means-tested benefits (all below) & 17.3 & 14.9 & 13.7 & 26.7 & 22.8 & 19.4 \\
\hline All welfare & 12.6 & 10.8 & 10.4 & 14.1 & 12.7 & 11.6 \\
\hline TANF & 12.6 & 10.7 & 10.1 & 14.0 & 12.6 & 10.9 \\
\hline Other public assistance & 12.5 & 10.7 & 9.6 & 13.8 & 12.4 & 9.0 \\
\hline SSI & 13.3 & 11.5 & 10.9 & 15.1 & 13.4 & 10.9 \\
\hline SNAP & 14.1 & 12.0 & 10.9 & 18.9 & 16.4 & 12.4 \\
\hline Public/subsidized housing & 13.1 & 11.4 & 11.4 & 15.6 & 14.6 & 13.4 \\
\hline Federal tax credits & 15.4 & 13.1 & 10.8 & 22.8 & 19.3 & 13.3 \\
\hline EITC & 14.6 & 12.4 & 10.5 & 20.1 & 17.0 & 11.6 \\
\hline Refundable child tax credit & 13.3 & 11.2 & 9.9 & 16.6 & 14.4 & 10.1 \\
\hline State tax credits & 12.5 & 10.7 & 9.6 & 13.9 & 12.6 & 9.2 \\
\hline
\end{tabular}

TABLE C2. Safety Net Effects on Family Income, 2008 (SPM Units Containing Children or Nonelderly Heads)

\begin{tabular}{|c|c|c|c|c|c|c|}
\hline & \multicolumn{3}{|c|}{ Remaining in Poverty } & \multicolumn{3}{|c|}{ Lifted above Poverty } \\
\hline & GA & IL & MA & GA & IL & MA \\
\hline Number of families & 445,394 & 501,266 & 247,544 & 157,777 & 188,097 & 122,575 \\
\hline Percent of pre-safety net poor & 73.8 & 72.7 & 66.9 & 26.2 & 27.3 & 33.1 \\
\hline Private income & $\$ 6,005$ & $\$ 6,358$ & $\$ 6,717$ & $\$ 11,905$ & $\$ 12,299$ & $\$ 9,582$ \\
\hline \multicolumn{7}{|l|}{ Average amount received } \\
\hline Social Security & $\$ 965$ & $\$ 757$ & $\$ 992$ & $\$ 6,880$ & $\$ 7,471$ & $\$ 6,288$ \\
\hline Unemployment & $\$ 196$ & $\$ 234$ & $\$ 301$ & $\$ 509$ & $\$ 807$ & $\$ 809$ \\
\hline Welfare & $\$ 86$ & $\$ 153$ & $\$ 544$ & $\$ 240$ & $\$ 302$ & $\$ 1,499$ \\
\hline SSI & $\$ 807$ & $\$ 861$ & $\$ 986$ & $\$ 1,397$ & $\$ 1,230$ & $\$ 2,451$ \\
\hline SNAP & $\$ 1,687$ & $\$ 1,982$ & $\$ 1,093$ & $\$ 1,727$ & $\$ 1,672$ & $\$ 1,554$ \\
\hline Public/subsidized housing & $\$ 642$ & $\$ 933$ & $\$ 921$ & $\$ 1,029$ & $\$ 1,286$ & $\$ 2,917$ \\
\hline EITC & $\$ 677$ & $\$ 708$ & $\$ 492$ & $\$ 1,914$ & $\$ 1,780$ & $\$ 1,151$ \\
\hline Refundable child tax credit & $\$ 110$ & $\$ 122$ & $\$ 126$ & $\$ 527$ & $\$ 549$ & $\$ 311$ \\
\hline State tax credits & $\$ 38$ & $\$ 35$ & $\$ 74$ & $\$ 37$ & $\$ 89$ & $\$ 173$ \\
\hline Gross income & $\$ 11,211$ & $\$ 12,143$ & $\$ 12,245$ & $\$ 26,164$ & $\$ 27,485$ & $\$ 26,735$ \\
\hline - Taxes & $-\$ 507$ & $-\$ 583$ & $-\$ 602$ & $-\$ 948$ & $-\$ 1,052$ & $-\$ 767$ \\
\hline -Work expenses & $-\$ 791$ & $-\$ 803$ & $-\$ 774$ & $-\$ 1,090$ & $-\$ 1,095$ & $-\$ 904$ \\
\hline Net income & $\$ 9,914$ & $\$ 10,757$ & $\$ 10,869$ & $\$ 24,126$ & $\$ 25,337$ & $\$ 25,064$ \\
\hline
\end{tabular}

Source: TRIM3 using 2008 American Community Survey. 
TABLE C3. SPM Poverty Gap, Total, and in Absence of Different Safety Net Programs, 2008 (\$ million unless otherwise specified)

\begin{tabular}{|c|c|c|c|c|c|c|}
\hline & \multicolumn{3}{|c|}{ Families with Related Children ${ }^{\mathrm{a}}$} & \multicolumn{3}{|c|}{$\begin{array}{l}\text { Nonelderly-Headed Families } \\
\text { without Related Children }\end{array}$} \\
\hline & GA & IL & MA & GA & IL & MA \\
\hline Number of families (thousands) & 1,288 & 1,641 & 792 & 1,892 & 2,448 & 1,378 \\
\hline Number of poor families (thousands) & 161 & 184 & 69 & 347 & 385 & 212 \\
\hline Poverty gap & 913 & 1,072 & 412 & 1,892 & 2,213 & 1,486 \\
\hline \multicolumn{7}{|c|}{ Poverty gap in absence of the following income or benefit source: } \\
\hline All public benefits (all below) & 3,534 & 4,285 & 2,151 & 3,302 & 4,028 & 2,764 \\
\hline Social Security & 1,276 & 1,440 & 610 & 2,563 & 2,967 & 1,991 \\
\hline Unemployment compensation & 965 & 1,171 & 465 & 1,969 & 2,308 & 1,564 \\
\hline All means-tested benefits (all below) & 2,993 & 3,634 & 1,801 & 2,512 & 3,124 & 2,136 \\
\hline All welfare (three items below) & 946 & 1,140 & 616 & 1,905 & 2,243 & 1,512 \\
\hline TANF & 938 & 1,108 & 547 & 1,892 & 2,213 & 1,490 \\
\hline SSF & 913 & 1,084 & 412 & 1,892 & 2,213 & 1,486 \\
\hline Other public assistance & 921 & 1,091 & 466 & 1,904 & 2,243 & 1,508 \\
\hline SSI & 1,110 & 1,296 & 569 & 2,166 & 2,553 & 1,768 \\
\hline SNAP & 1,608 & 1,916 & 630 & 2,062 & 2,488 & 1,600 \\
\hline Public/subsidized housing & 1,187 & 1,479 & 682 & 1,992 & 2,412 & 1,637 \\
\hline $\begin{array}{l}\text { Federal EITC and refundable child tax credit } \\
\text { (combined effect of following two items) }\end{array}$ & 1,480 & 1,699 & 615 & 1,935 & 2,256 & 1,505 \\
\hline Federal EITC & 1,321 & 1,524 & 551 & 1,935 & 2,256 & 1,505 \\
\hline Federal refundable child tax credit & 994 & 1,166 & 456 & 1,892 & 2,213 & 1,486 \\
\hline State EITC/Georgia Low Income Credit & 922 & 1,089 & 429 & 1,900 & 2,215 & 1,489 \\
\hline \multicolumn{7}{|c|}{ Reduction in poverty gap from following income or benefit source:b } \\
\hline All public benefits (all below) & 2,622 & 3,213 & 1,739 & 1,410 & 1,815 & 1,278 \\
\hline Social Security & 364 & 368 & 198 & 671 & 754 & 504 \\
\hline Unemployment compensation & 52 & 99 & 53 & 77 & 95 & 78 \\
\hline All means-tested benefits (all below) & 2,081 & 2,562 & 1,389 & 620 & 911 & 650 \\
\hline All welfare (three items below) & 33 & 68 & 205 & 13 & 30 & 26 \\
\hline TANF & 25 & 36 & 135 & 1 & 0 & 4 \\
\hline SSF & 0 & 12 & 0 & 0 & 0 & 0 \\
\hline Other public assistance & 8 & 19 & 54 & 13 & 30 & 22 \\
\hline SSI & 198 & 223 & 157 & 274 & 340 & 281 \\
\hline SNAP & 695 & 844 & 218 & 170 & 275 & 114 \\
\hline Public/subsidized housing & 275 & 407 & 270 & 100 & 199 & 151 \\
\hline $\begin{array}{l}\text { Federal EITC and refundable child tax credit } \\
\text { (combined effect of following two items) }\end{array}$ & 568 & 626 & 203 & 43 & 43 & 18 \\
\hline Federal EITC & 409 & 452 & 139 & 43 & 43 & 18 \\
\hline Federal refundable child tax credit & 82 & 93 & 44 & 0 & 0 & 0 \\
\hline State EITC/Georgia Low Income Credit & 10 & 17 & 17 & 8 & 2 & 3 \\
\hline
\end{tabular}


TABLE C3. SPM Poverty Gap, Total, and in Absence of Different Safety Net Programs, 2008 (Continued) (\$ million unless otherwise specified)

\begin{tabular}{|c|c|c|c|c|c|c|}
\hline & \multicolumn{3}{|c|}{ Families with Related Children ${ }^{a}$} & \multicolumn{3}{|c|}{$\begin{array}{l}\text { Nonelderly-Headed Families } \\
\text { without Related Children }\end{array}$} \\
\hline & GA & IL & MA & GA & IL & MA \\
\hline \multicolumn{7}{|c|}{ Percent reduction in poverty gap from following income or benefit source:c } \\
\hline All public benefits (all below) & 74.2 & 75.0 & 80.8 & 42.7 & 45.1 & 46.2 \\
\hline Social Security & 28.5 & 25.6 & 32.4 & 26.2 & 25.4 & 25.3 \\
\hline Unemployment compensation & 5.4 & 8.4 & 11.3 & 3.9 & 4.1 & 5.0 \\
\hline All means-tested benefits (all below) & 69.5 & 70.5 & 77.1 & 24.7 & 29.2 & 30.4 \\
\hline All welfare (three items below) & 3.5 & 5.9 & 33.2 & 0.7 & 1.3 & 1.7 \\
\hline TANF & 2.7 & 3.3 & 24.7 & 0.0 & 0.0 & 0.3 \\
\hline SSF & 0.0 & 1.1 & 0.0 & 0.0 & 0.0 & 0.0 \\
\hline Other public assistance & 0.9 & 1.8 & 11.5 & 0.7 & 1.3 & 1.4 \\
\hline SSI & 17.8 & 17.2 & 27.6 & 12.7 & 13.3 & 15.9 \\
\hline SNAP & 43.2 & 44.1 & 34.6 & 8.2 & 11.1 & 7.1 \\
\hline Public/subsidized housing & 23.1 & 27.5 & 39.6 & 5.0 & 8.3 & 9.2 \\
\hline $\begin{array}{l}\text { Federal EITC and refundable child tax credit } \\
\text { (combined effect of following two items) }\end{array}$ & 38.4 & 36.9 & 33.0 & 2.2 & 1.9 & 1.2 \\
\hline Federal EITC & 30.9 & 29.7 & 25.3 & 2.2 & 1.9 & 1.2 \\
\hline Federal refundable child tax credit & 8.2 & 8.0 & 9.6 & 0.0 & 0.0 & 0.0 \\
\hline State EITC/Georgia Low Income Credit & 1.0 & 1.6 & 4.0 & 0.4 & 0.1 & 0.2 \\
\hline
\end{tabular}

Source: TRIM3 using 2008 American Community Survey.

a. Families with related children include families with elderly heads that also have related children.

b. The poverty gap in the absence of the income or benefit source, minus the actual poverty gap.

c. The reduction in the poverty gap by the income or benefit source, divided by the poverty gap in the absence of the income or benefit source. 


\section{NOTES}

1. The ITWG report can be found at http://www.census.gov/hhes/www/poverty/SPM_TWGObservations.pdf.

2. The means-tested programs included in the analysis account for the largest federal programs outside health and education programs for people with low incomes (Spar 2011).

3. The federal government finances most of the extended benefit program. All but one state take the option to pay EUC before EB, and EB has been funded completely by the federal government from February 2009 through December 1, 2010. See Vroman (2010).

4. “Comparison of State Unemployment Laws 2008," http://www.ows.doleta.gov/unemploy/uilawcompar/2008/ comparison2008.asp.

5. See discussion of Federal Housing Assistance in U.S. Ways and Means Committee (2009).

6. The refundable portion of the child tax credit equals the amount of the child tax credit exceeding tax liability, capped at 15 percent of earnings exceeding $\$ 8,500$ in 2008 . Families with more than two children have the choice of an alternative cap equal to the amount of the families' Social Security plus Medicare payroll tax minus their refundable EITC.

7. The essential elements of the SPM were originally developed by a National Academy of Sciences Panel and published in 1995 (Citro and Michael 1995). Subsequently, the Census Bureau conducted and published numerous refinements of the measure. In 2010, the Interagency Technical Working Group provided recommendations for the development of the SPM, drawing from the NAS report and incorporating lessons from subsequent research (U.S. Census Bureau 2010).

8. The SPM thresholds were provided by Thesia Garner of the Bureau of Labor Statistics and include out-of-pocket medical expenses. The thresholds vary depending on family size and number of children. As explained in appendix A, we adjust the housing portion of the threshold for differences in housing costs by Super-PUMA within the state and the medical portion for differences in the health and insurance status of a family, and elderly/nonelderly status. Given so many different dimensions, we show the average threshold applied in each state for families with two adults and two children.

9. We also include elderly people who live in units headed by a nonelderly person. 
10. These results show the effect of eliminating either all benefits or a single benefit from income and then recomputing the SPM.

11. Our TANF estimates for Illinois include families receiving solely state-funded (SSF) benefits.

12. The results discussed here are for families with children. Overall results for families with children or a nonelderly head are displayed in appendix table $\mathrm{C} 2$.

13. Trudi Renwick advised us in our efforts to replicate the Census Bureau methodology.

14. Our work predated the Census Bureau's more recent work that uses five years of ACS data and calculates different geographic adjustments by whether the household rents, owns with a mortgage, or owns without a mortgage (Renwick 2011), so these enhancements are not captured.

15. The Super-PUMA is a geographic area composed of a population of 400,000 or more. It does not span state lines. SuperPUMAs are composed of PUMAs (Public Use Microdata Areas) that reflect population groups of at least 100,000. We did not calculate our adjustments at the PUMA level out of concern that it represents too small a geographic area.

16. The housing portion of the SPM threshold equals 46.0 percent for renters, 46.8 percent for homeowners with mortgages, and 35.2 percent for homeowners without mortgages (Garner 2011b).

17. See Passel, Van Hook, and Bean (2006).

18. We used the Current Population Survey (CPS) to estimate this regression. Since all the elements of the ACS "other income" are reported separately on the CPS, we could create a combined "other income" variable to match the one represented in the ACS. The multinomial logit regression was estimated to predict the share of income attributable to UI, to child support, and to other income. See Martinez-Schiferl (2011) for a detailed description of these procedures. 


\section{REFERENCES}

Citro, Constance F., and Robert T. Michael, eds. 1995. Measuring Poverty: A New Approach. Washington, DC: National Academy Press.

Cunnyngham, Karen, and Laura Castner. 2010. "State Supplemental Nutrition Assistance Program Participation Rates in 2008.” Washington, DC: Mathematica Policy Research.

Gabe, Thomas. 2008. Social Security's Effect on Child Poverty. Washington, DC: Congressional Research Service.

Garner, Thesia I. 2010. "Supplemental Poverty Measure Thresholds and the Estimation Sample." Washington, DC: U.S. Department of Labor, Bureau of Labor Statistics.

. 2011a. "Supplemental Poverty Measure Thresholds: Laying the Foundation.” Washington, DC: U.S. Department of Labor, Bureau of Labor Statistics.

- 2011b. "Preliminary 2008 Supplementary Poverty Measurement FCSUM Thresholds for Consumer Units with Two Adults and Two Children." Washington, DC: U.S. Department of Labor, Bureau of Labor Statistics, Office of Prices and Living Conditions, Division of Price and Index Number Research.

Levitis, Jason, and Jeremy Koulish. 2008. State Earned Income Tax Credits: 2008 Legislative Update. Washington, DC: Center on Budget and Policy Priorities.

Martinez-Schiferl, Michael. 2011. "Reports of Unemployment Compensation on the American Community Survey: A Data Note." Washington, DC: The Urban Institute.

Passel, Jeffrey S., Jennifer Van Hook, and Frank D. Bean. 2006. "Narrative Profile with Adjoining Tables of Unauthorized Migrants and Other Immigrants, Based on Census 2000: Characteristics and Methods.” Warrington, PA: Sabre Systems Inc.

Renwick, Trudi. 2011. "Geographic Adjustments of Supplemental Poverty Measure Thresholds: Using the American Community Survey Five-Year Data on Housing Costs.” Washington, DC: U.S. Census Bureau. 
Ruggles, Steven, Matthew Sobek, Trent Alexander, Catherine A. Fitch, Ronald Goeken, Patricia Kelly Hall, Miriam King, and Chad Ronnander. 2000. Integrated Public Use Microdata Series: Version 4.1 (Machine-readable database). Minneapolis: Minnesota Population Center [producer and distributor].

Short, Kathleen. 2001. “Experimental Poverty Measures: 1999.” Washington, DC: U.S. Census Bureau.

— 2011. "Who Is Poor? A New Look with the Supplemental Poverty Measure.” Washington, DC: U.S. Census Bureau.

Short, Kathleen S., and Trudi J. Renwick. 2010. “Supplemental Poverty Measure: Preliminary Estimates for 2008.” Washington, DC: U.S. Census Bureau.

Spar, Karen. 2011. Federal Benefits and Services for People with Low Income: Programs, Policy and Spending, FY 2008-2009. Washington, DC: Congressional Research Service.

U.S. Census Bureau. 2010. "Observations from the Interagency Technical Working Group on Developing a Supplemental Poverty Measure.” Washington, DC: U.S. Census Bureau. http://www.census.gov/hhes/www/poverty/SPM_ TWGObservations.pdf.

U.S. Ways and Means Committee. 2009. Background Material and Data on the Programs within the Jurisdiction of the Committee on Ways and Means (the Green Book). Washington, DC: Government Printing Office.

Vroman, Wayne. 2009. "Unemployment Insurance: Current Situation and Potential Reforms." Washington, DC: The Urban Institute.

. 2010. "The Great Recession, Unemployment Insurance, and Poverty." Paper prepared for "Reducing Poverty and Economic Distress after ARRA,” Washington, D.C., January 15. 


\section{ABOUT THE AUTHORS}

Laura Wheaton is a senior research associate in the Urban Institute's Income and Benefits Policy Center.

Linda Giannarelli is a senior fellow in the Income and Benefits Policy Center.

Michael Martinez-Schiferl is a research associate in the Income and Benefits Policy Center.

Sheila Zedlewski is an Institute fellow in the Income and Benefits Policy Center. 
